\title{
Quaternary glaciation of the Himalayan-Tibetan orogen
}

\author{
LEWIS A. OWEN, ${ }^{1 *}$ MARC W. CAFFEE, ${ }^{2}$ ROBERT C. FINKEL ${ }^{3}$ and YEONG BAE SEONG ${ }^{4}$ \\ ${ }^{1}$ Department of Geology, University of Cincinnati, Cincinnati, Ohio, USA \\ ${ }^{2}$ Department of Physics/PRIME Laboratory, Purdue University, West Lafayette, Indiana, USA \\ ${ }^{3}$ Center for Accelerator Mass Spectrometry, Lawrence Livermore National Laboratory, Livermore, California, USA \\ ${ }^{4}$ Department of Earth and Environmental Sciences, Korea University, Seoul, Korea
} 0267-8179.

ABSTRACT: Glacial geological evidence from throughout the Himalayan-Tibetan orogen is examined to determine the timing and extent of late Quaternary glaciation in this region and its relation to similar changes on a global scale. The evidence summarised here supports the existence of expanded ice caps and extensive valley glacier systems throughout the region during the late Quaternary. However, it cannot yet be determined whether the timing of the extent of maximum glaciation was synchronous throughout the entire region or whether the response was more varied. The lack of organic material needed for radiocarbon dating has hindered past progress in glacial reconstruction; however, application of optically stimulated luminescence and terrestrial cosmogenic radionuclide methods has recently expanded the number of chronologies throughout the region. Limits to the precision and accuracy available with these methods and, more importantly, geological uncertainty imposed by processes of moraine formation and alteration both conspire to limit the time resolution on which correlations can be made to Milankovitch timescales (several ka). In order to put all studies on a common scale, well-dated sites have been re-evaluated and all the published terrestrial cosmogenic nuclide ages for moraine boulders and glacially eroded surfaces in the Himalayan-Tibetan orogen have been recalculated. Locally detailed studies indicate that there are considerable variations in the extent of glaciation from one region to the next during a glaciation. Glaciers throughout monsoon-influenced Tibet, the Himalaya and the Transhimalaya are likely synchronous both with climate change resulting from oscillations in the South Asian monsoon and with Northern Hemisphere cooling cycles. In contrast, glaciers in Pamir in the far western regions of the Himalayan-Tibet orogen advanced asynchronously relative to the other regions that are monsooninfluenced regions and appear to be mainly in phase with the Northern Hemisphere cooling cycles. Broad patterns of local and regional variability based on equilibrium-line altitudes have yet to be fully assessed, but have the potential to help define changes in climatic gradients over time. Copyright (C) 2008 John Wiley \& Sons, Ltd.

Additional supporting information may be found in the online version of this article.

KEYWORDS: mountain glaciation; Himalaya; Tibet; geochronology; monsoon.

\section{Introduction}

The Himalaya-Tibetan orogen is the most glaciated mountain region outside of the polar realms $\left(\sim 126200 \mathrm{~km}^{2}\right.$; Haeberli et al., 1989). The economies of countries within and bordering the orogen are mostly agriculture based and are thus sensitive to variations in the glacial and hydrological systems that provide much of the water to these regions. The Quaternary geological archive on the Tibetan Plateau can be used to reconstruct and model the effects of environmental change on the regional

* Correspondence to: L. A. Owen, Department of Geology, University of Cincinnati, Cincinnati $\mathrm{OH}$ 45221, USA.

E-mail: lewis.owen@uc.edu

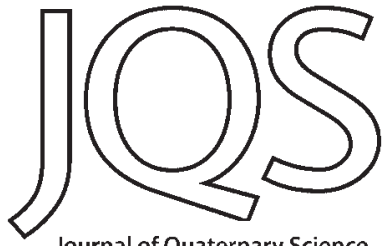

Journal of Quaternary Science climate and hydrology of the orogen and adjacent regions. Changes in the extent of glaciers and snow cover on the Tibetan Plateau provide significant feedbacks in climate modelling, which requires understanding the nature of glacial fluctuations (Dey and Bhanu Kumar, 1982; Dey et al., 1985; Bush, 2000). Tibet is also an ideal natural laboratory to examine the relationship between global climate and the processes of continental-continental collisions, tectonic aneurysm (Zeitler et al., 2001) and glacial buzzsaw (Porter, 1989; Brozovic et al., 1997) models.

The extent and timing of glaciation and the associated hydrological and climatic responses in the Himalayan-Tibetan orogen are poorly defined owing to the inaccessibility to the region. Accurate reconstructions of former ice extent have been hindered by the difficulty in distinguishing glacial from 
non-glacial landforms. There are few opportunities to apply numerical dating tools, many of which have large errors, which could define the ages of landforms and that in turn can establish regional correlations (Benn and Owen, 1998, 2002). Reconstructions of the extent of former glaciations vary considerably between researchers and few of these studies have been rigorously evaluated in light of new methodologies. In this paper, we review the current knowledge on the Quaternary glaciation of the Himalaya-Tibetan region and critically evaluate the reconstructions of the timing and extent of Quaternary glaciation. We focus mainly on the late Quaternary and select important regions within the orogen for detailed consideration.

This paper builds on a series of research papers published in three Quaternary International volumes (Owen and Lehmkuhl, 2000; Owen and Zhou, 2002; Yi and Owen, 2006), summaries for the Global Mapping Project of INQUA on the glacial geology of each country in central Asia (Ehlers and Gibbard, 2004) and a review by Lehmkuhl and Owen (2005).

\section{Physical setting}

Collision of the Indian and Eurasian continental plates, initiated ca. 50 Ma ago (Yin and Harrison, 2000), produced the Himalayan-Tibetan orogen. Geologically, the region is a complex assemblage of rocks of different ages that are still being actively deformed by the continued northward movement of the Indian plate at $\sim 50 \mathrm{~mm} \mathrm{a}^{-1}$ (DeMets et al., 1994; Yin and Harrison, 2000). The region stretches $\sim 2000 \mathrm{~km}$ eastwest and $\sim 1500 \mathrm{~km}$ north-south, and has an average altitude of $\sim 5000 \mathrm{~m}$ above sea level (a.s.I.) (Fielding et al., 1994). A series of approximately east-west trending mountain ranges are present. These include, from south to north, the Siwaliks, Lesser Himalaya, Greater Himalaya, Transhimalaya, Nyainqentanggulha Shan, Tanggula Shan, Bayan Har Shan, Kunlun Shan, Qilian Shan and Pamir. The Tian Shan and Altai Mountains north of the Tibetan Plateau are a distant manifestation of the continental-continental collision and will not be considered.
We focus on the contiguous mountain mass to the south and south-west of the great deserts of China and Mongolia (Fig. 1).

Two climatic systems dominate this vast region: the midlatitude westerlies and the South Asian monsoon (Benn and Owen, 1998; Fig. 2). Long-term variability (thousands of years) of the mid-latitude westerlies and the South Asian summer monsoon is linked to changes in Northern Hemisphere insolation, while shorter-term variability (years to decades) is attributed to changes within the climate system, such as variation in Eurasian snow cover, the El Niño-Southern Oscillation, and tropical sea surface temperatures (Hahn and Shukla, 1976; Dey and Bhanu Khumar, 1982; Dickson, 1984; Sirocko et al., 1991; Prell and Kutzbach, 1992; Soman and Slingo, 1997; Bush, 2000, 2002; Rupper, 2007). In addition, model results suggest that recent anthropogenic forcing (e.g. greenhouse gas, land cover change) is becoming important in controlling variations in the Asian monsoon (Wake et al., 2001).

Most of the southern and eastern region experiences a pronounced summer precipitation maximum, reflecting moisture advected northwards from the Indian Ocean by the south-west monsoon (Murakami, 1987). Summer precipitation declines sharply from south to north across the main Himalayan chain and is low over western Tibet (Fig. 3(A) and (B)). There is a winter precipitation maximum only in the extreme west of the orogen due to the influence of winter westerly winds bringing moisture from the Mediterranean, Black and Caspian seas.

Snow and ice accumulation varies across the orogen as a consequence of changing moisture contents of air masses forced over the Himalayan-Tibetan orogen. The orographic forcing produces drier air that eventually descends and warms the northern slopes of the Transhimalaya and the northern edge of the Tibetan Plateau. These winds may have a major control on glacier formation. A combination of the above factors results in the variation of equilibrium-line altitudes (ELAs) from $4300 \mathrm{~m}$ a.s.I. in south-east Tibet to over $6000 \mathrm{~m}$ a.s.I. in western Tibet (Owen and Benn, 2005). The seasonal distribution of precipitation creates glaciers of the summer accumulation type, with maxima in accumulation and ablation occurring more or less simultaneously during the summer, in most of the region (Ageta and Higuchi, 1984; Owen and Derbyshire, 1989; Benn and Owen, 1998; Ageta and Kadota, 1992; Kulkarni,

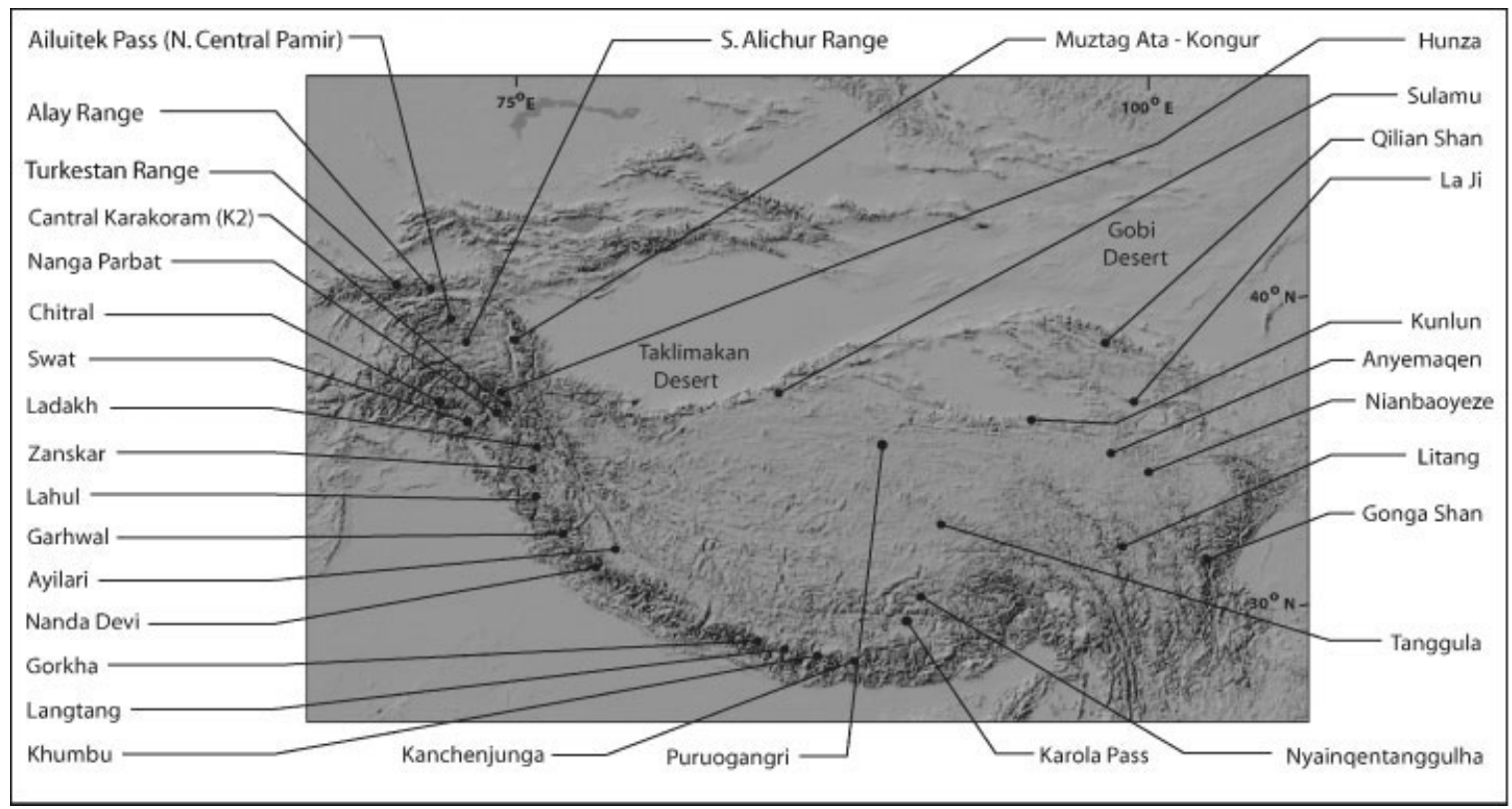

Figure 1 Major study regions in the Himalayan-Tibetan orogen that are referenced in the text 

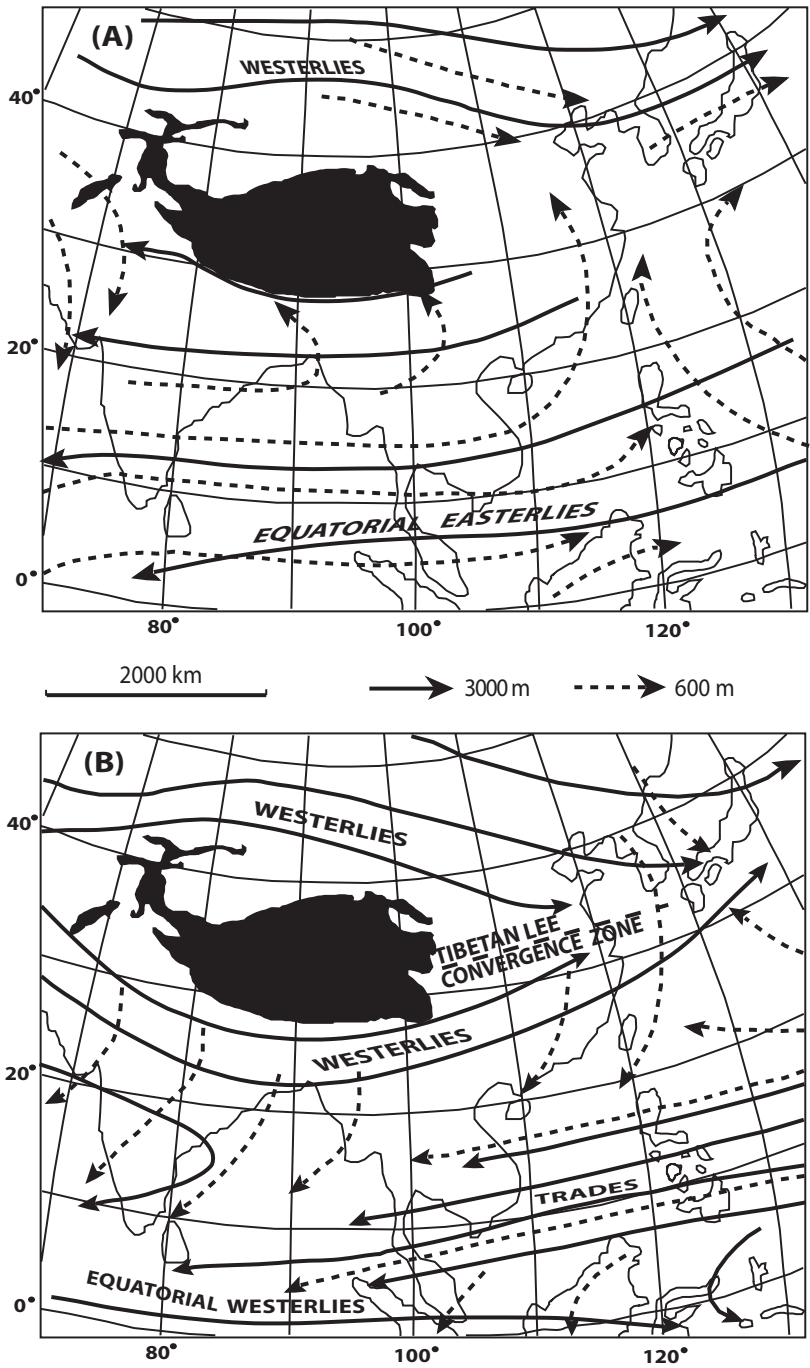

Figure 2 Characteristic air circulation over the Eastern Hemisphere for (A) summer (July) and (B) winter (January). The solid lines indicate airflow at $\sim 3000 \mathrm{~m}$ for winter (A) and $\sim 6000 \mathrm{~m}$ a.s.l. for summer in (B) and the dashed lines at $\sim 600 \mathrm{~m}$ in (A) and (B). Names refer to air systems. The area of Tibet and the Himalaya is shown in black. Adapted from Barry and Chorley (2003)

1992; Nijampurkar and Rao, 1992). The summer accumulation maximum reflects high precipitation during the summer monsoon, when moisture-bearing air masses originating over the Indian Ocean bring snow to high altitudes in the Himalaya and western Tibet (Yasunari and Inoue, 1978; Higuchi et al., 1982; Ageta and Higuchi, 1984). Glacier ablation is also at a maximum during the summer, when high temperatures result from direct solar heating, advected sensible heat, and latent heat released by condensation during deep atmospheric convection (Webster, 1987a,b). In contrast, winters are cold and relatively dry, although heavy snowfalls can occur in association with westerly winds, particularly in the western parts of the Himalayan-Tibetan orogen (Inoue, 1978; Benn and Owen, 1998). Glacier accumulation occurs by direct snowfall, blowing snow and avalanching. The relative importance of these three processes varies considerably between glaciers. Avalanching plays an important role in many catchments due to the widespread occurrence of high, steep mountain sides that capture, but cannot retain snowfall (Benn and Owen, 1998; Benn and Lehmkuhl, 2000). Continuous, thick debris cover insulates the underlying ice, and can significantly reduce ablation (Inoue, 1977).
Derbyshire (1982) recognised three main glacial regimes across the Himalayan-Tibetan region. These included glaciers with a continental regime, which by extent are the most dominant, spanning the Transhimalaya and western and central Tibet; a maritime regime in the Himalaya and eastern Tibet, which can be subdivided into a western group and an eastern (monsoon-dominated) group; and a transitional regime in the northeastern part of Tibet. Derbyshire (1982) highlighted the differences in the geomorphology, lithofacies and land systems types associated with each glacier regime. This has been further expanded by research in specific regions of the Himalaya (e.g. Owen and Derbyshire, 1988, 1989; Benn and Owen, 2002). However, given the vast scale of the region there is generally an absence of detailed geomorphic and sedimentological studies of Himalaya and Tibetan glacial systems.

\section{Extent of glaciation}

Reconstructing the extent of glaciation throughout the Himalayan-Tibetan orogen has a long history. Early explorers into the region included Thompson (1849), Cunningham (1854), Godwin-Austin (1864) and Conway (1894). They described the geomorphic and sedimentary features they saw on their expeditions, but commented little on their significance. Early important contributions to the Quaternary geology were presented by Drew (1873), Dainelli, (1922, 1934, 1935), Norin (1925), Trinkler (1930), Misch (1935), de Terra and Paterson (1939) and Paffen et al. (1956) for regions throughout the western end of the Himalayan-Tibetan orogen. The first comprehensive map for the entire Himalayan-Tibetan region of the extent of glaciation for the Last Glacial was provided by Klute (1930; Fig. 4(A)). This was later modified by Frenzel (1960), who used the detailed work, based on the observations of the earliest explorers, of von Wissmann (1959) (Fig. 4(B)).

During the late 1980s and early 1990s, Kuhle (1985, 1986, 1987, 1988a,b, 1990a,b, 1991, 1993, 1995) argued that an extensive ice sheet covered most of the Tibetan Plateau during the Last Glacial (Fig. 4(C)). This was disputed by many and it stimulated much research in Tibet, especially as China began to open its borders to western scientists and strengthened its international research collaborations. Over the past few decades, numerous publications have presented the evidence against an extensive ice sheet (Derbyshire, 1987; Zheng, 1989; Shi, 1992; Hövermann et al., 1993a,b; Lehmkuhl, 1995, 1998; Rutter, 1995; Lehmkuhl et al., 1998; Zheng and Rutter, 1998; Schäfer et al., 2002; Owen et al., 2003a). Now it is generally accepted that a large ice sheet did not cover the Tibetan Plateau, at least not during the past few glacial cycles.

Most recently, Chinese workers have compiled synthesis maps to show the probable extent of former glaciation across the Tibetan Plateau (Shi et al., 1986, 1993, 2005; Liu et al., 1988; Shi, 1988, 1992; Li et al., 1991; Fig. 4(D)). Li et al. (1991) perhaps provide the best reconstruction of the maximum extent of glaciation for the entire Himalaya and Tibetan Plateau for the last glacial cycle. However, it is unlikely that the reconstructed glaciers reached their maximum extents at the same time during the Last Glacial (see discussion below). Recently, remote sensing combined with field mapping is allowing extensive areas to be mapped in detail (e.g. Stroeven et al., 2008).

The inconsistencies between the various reconstructions of former ice extent stem from three main reasons. Firstly, the immense size and inaccessibility of the region have led many early researchers to extrapolate their former glacier margins through terra incognito lacking strong geological evidence. The 


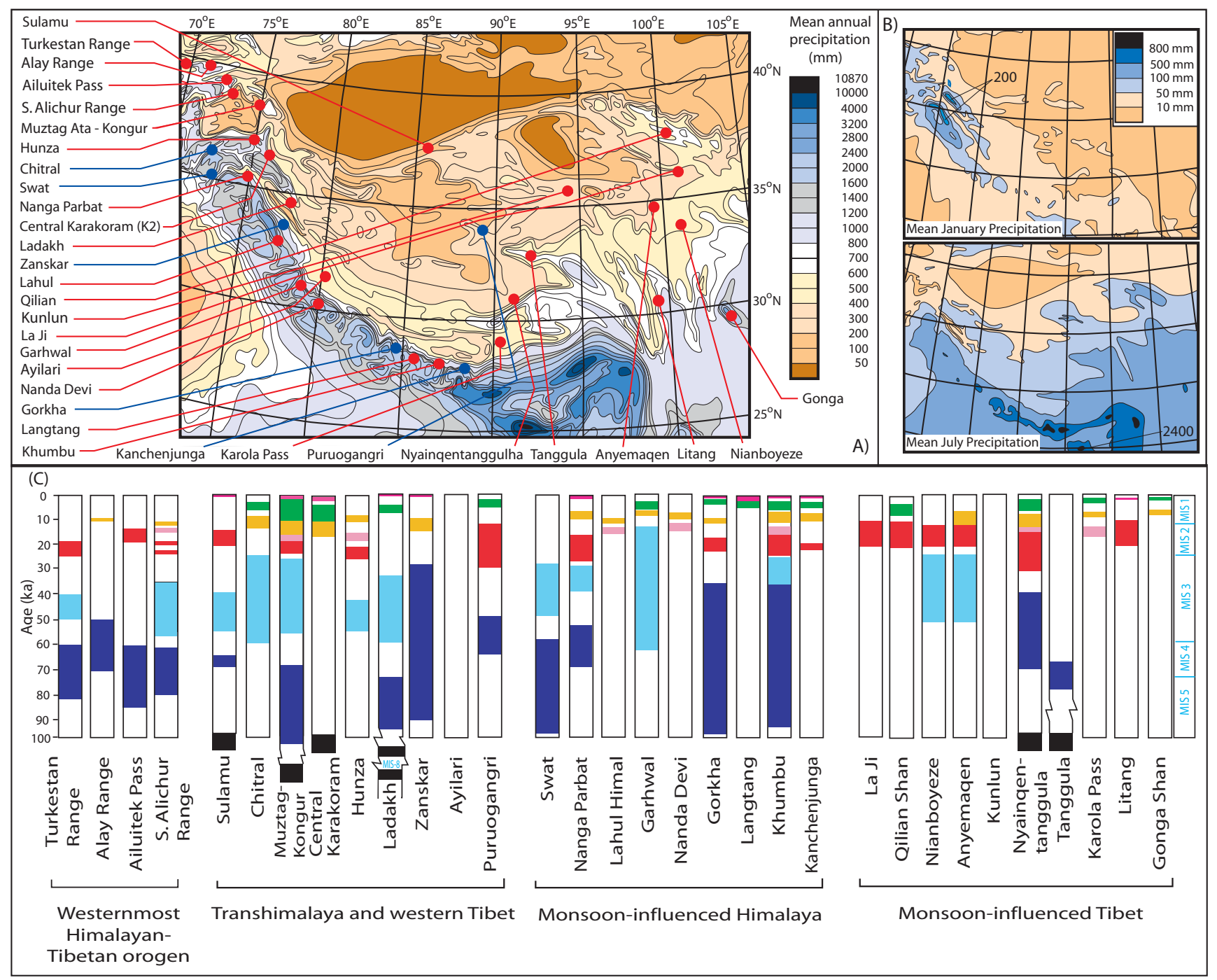

Figure 3 Contemporary mean annual (A) and mean January and July (B) precipitation across Tibet and the bordering regions showing (C) the locations and glacial chronologies that have been numerically dated throughout the Himalaya and Tibet (expanded from Owen et al., 2005, and data from Shiraiwa, 1993; Sharma and Owen, 1996; Phillips et al., 2000; Richards et al., 2000a,b; Owen et al., 2001, 2002a,b, 2003a,b,c, 2005, 2006a,b; Schäfer et al., 2002; Tsukamoto et al., 2002; Yi et al., 2002; Finkel et al., 2003; Zech et al., 2003, 2005; Barnard et al., 2004a,b, 2006a,b; Meriaux et al., 2004; Spencer and Owen, 2004; Chevalier et al., 2005; Abramowski et al., 2006; Colgan et al., 2006; Seong et al., 2007, 2008a). The red dots in part (A) highlight regions where TCN surface exposure dating has been undertaken. The colour bars in part (C) represent the likely duration of each glacial advance based on the best estimate of the ages of moraines presented in the original publications. A tentative correlation is suggested by applying similar colours to the bars. Marine Isotope Stages (MISs) are taken from Martinson et al. (1987) and Shackleton et al. (1990)

recent increased availability and use of remote-sensing technologies has reduced this problem considerably. Access to many regions has considerably improved since the 1970 s after new roads were built across the region.

The second reason stems from the misinterpretation of sediment and landforms. Owen et al. (1998) highlighted that much of the landform and sedimentary record within the Himalayan-Tibetan orogen has undergone intense mass wasting, as well as fluvial and glacial erosion. This has often resulted in the destruction of diagnostic morphologies and in rapid reworking of sediment and landforms (Derbyshire, 1983; Owen, 1991; Benn and Owen, 2002). In the case of till, one common result is that they are commonly confused with debris flow or rock avalanche deposits, and vice versa. This is particularly problematic when mass movement deposits contain faceted and striated clasts, which pose the question as to whether the sediments were derived directly or indirectly from glacial ice or from reworked and resedimented tills. The situation may be further complicated when till clasts derived from sediments within the passive flow paths of steep glaciers are left unstriated. Owen et al. (1998) termed this the 'diamicton problem'.

Genetic discrimination between landforms and the sediments (notably diamictons) can be made by careful sedimentological and geomorphic analysis for palaeoenvironmental reconstructions (Derbyshire, 1982, 1983; Derbyshire and Owen, 1990; Owen and Derbyshire, 1988, 1989; Li et al., 1984; Fort and Derbyshire, 1988; Hewitt, 1999). Owen (1988, 1991, 1993) and Benn and Owen (2002) presented a set of sedimentological and geomorphic criteria based on contemporary and Quaternary examples from the Karakoram of northern Pakistan and the Himalaya of northern India that provides a useful framework for accurate reconstructions of former glacier extent.

The third reason is a consequence of poor chronological control for the glacial successions. Defining the ages of landforms and sediments throughout much of the HimalayanTibetan orogen has been particularly difficult because of the 

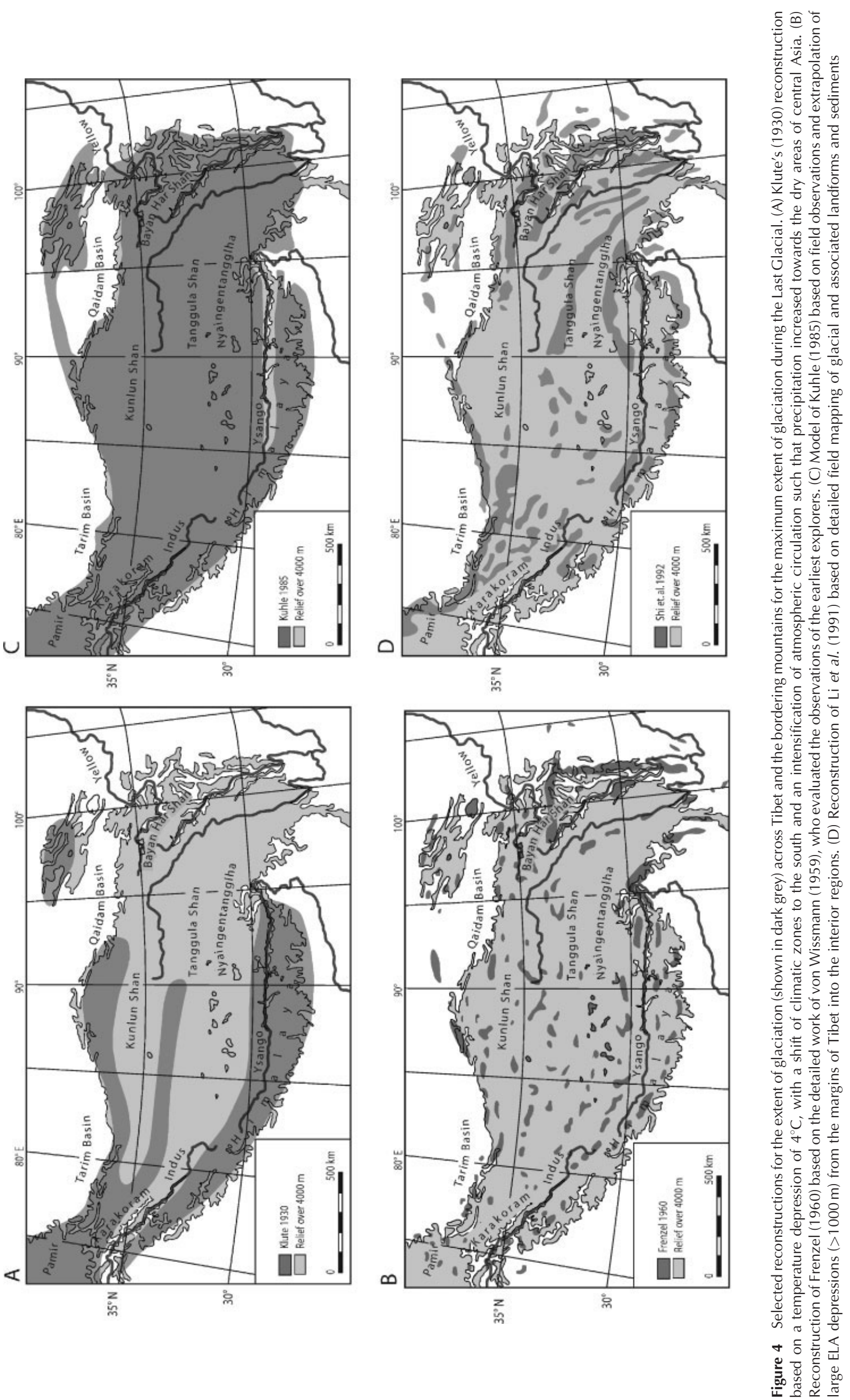
lack of organic material for radiocarbon dating. Radiocarbon dates are available for the wetter parts of the HimalayanTibetan region, but most are limited to Holocene proglacial deposits, which poorly define the timing of glaciation (Röthlisberger and Geyh, 1985; Lehmkuhl, 1995, 1997). The newly developing techniques of optically stimulated luminescence (OSL) and terrestrial cosmogenic nuclide (TCN) surface exposure dating are now allowing glacial successions throughout Tibet and the bordering mountains to be dated and correlated more accurately (see next section). Many of the reconstructions are based on correlating landforms, which have not been numerically dated, across vast regions. The resultant reconstructions are spurious when the landforms are not of the same age.

Despite these problems, there is substantial literature that presents detailed maps of the former extent of glaciation for specific areas throughout the Himalayan-Tibetan orogen. These are described in more detail in Ehlers and Gibbard (2004) and summarised in Lehmkuhl and Owen (2005). This shows that former glaciation was dominated by extensive valley glacier systems and expanded ice caps.

The extent of glaciation between adjacent regions within the Himalayan-Tibetan orogen can vary considerably. This is well illustrated across a stretch of northern Pakistan and northern India for glaciation during the Lateglacial at about 14-16 ka (Fig. 3). In the Hunza valley to the north-east, for example, glaciers only advanced a few kilometres from their present position, whereas in the Central Karakoram to the east an extensive valley glacier system extending more than $100 \mathrm{~km}$ from the present ice margin occurred (Owen et al., 2002a; Seong et al., 2007). To the south-east of these regions, in Ladakh, there is little evidence of a glacier advance at this time, and when glaciers did advance they were restricted to not more than a few kilometres from their present ice margins (Owen et al., 2006a) with ELA depressions ( $\triangle E L A s)$ of a few hundred metres. To the south of Ladakh, in the Lahul Himalaya, glaciers advanced more than $100 \mathrm{~km}$ beyond their present positions at this time (Owen et al., 2001). These contrasts in the extent of glaciation within a relatively small region of the HimalayanTibetan orogen highlight the important local climatic gradients and the strong topographic controls.

\section{Timing of glaciation}

Early studies of glaciation in the Himalayan-Tibetan orogen concentrated on developing relative glacial chronologies using morphostratigraphy aided by relative weathering studies (e.g. Burbank and Kang, 1991; Hövermann et al., 1993a,b; Hövermann and Lehmkuhl, 1994; Lehmkuhl, 1995, 1997, 1998; Owen et al., 1997; Lehmkuhl et al., 2000) and soil development (e.g. Bäumler et al., 1997; Guggenberger et al., 1998; Zech et al., 2000). These were supplemented by the application of radiocarbon methods. The first significant geochronological study was undertaken by Röthlisberger and Geyh (1985), who obtained 68 radiocarbon dates from the forelands of 16 different glaciers throughout the Himalaya and Karakoram Mountains. The dates showed significant advances at ca. 19 000, 12 700, 7400, 4900-4600, 3700-3100, 2700$2100,1700-1500,1200-950,800,500$ and $400-100{ }^{14} \mathrm{C}$ a BP. Subsequent studies present only a few radiocarbon ages (e.g. Derbyshire et al., 1991; Pachur et al., 1994; Mann et al., 1996).

With the development of luminescence dating throughout the 1980s and 1990s, luminescence methods were applied to many of the glacial successions throughout Himalaya and
Tibet. Of note was the work by Derbyshire et al. (1984), who provided some of the first ages on glaciogenic sediments in their study of the upper Hunza valley in Pakistan. Unfortunately, no descriptions of the methods were provided and it is difficult to evaluate their validity critically. However, later studies by Owen et al. (2002a) and Spencer and Owen (2004) support the ages presented in Derbyshire et al. (1984).

The most comprehensive application of luminescence dating to glacial successions in the Himalayan-Tibetan orogen was undertaken by Richards (1999). He provided a suite of OSL ages for moraines in northern Pakistan (Richards et al., 2000a) and the Khumbu Himal in Nepal (Richards et al., 2000b). The luminescence dating was applied to proglacial sediments beneath and above tills, and supraglacial sediments intercalated within tills to provide OSL ages that were maximum, minimum and contemporaneous with glacial advances. Significant problems, however, are associated with the application of luminescence dating to glaciogenic and associated sediments. These include partial bleaching, dose rate changes over time (particularly with regard to changing moisture content), and in the case of Himalayan sediments, poor sensitivity and the low brightness of quartz. An incorrect estimate for moisture content, for example, can result in a $1 \%$ difference in age for every $1 \%$ difference in moisture content. Partial bleaching is probably the greatest problem, however, and can result in an overestimate of the OSL age. As such, OSL ages under most circumstances may be considered as maximum age estimates. These factors are discussed in detail in Richards (2000) and Fuchs and Owen (2008). An assessment of these factors and the uncertainty associated with the method can be made by examining the protocols, methods and calculations used to determine the OSL ages. Unfortunately, many published results do not provide sufficiently detailed data and descriptions to assess and independently calculate the OSL ages. This makes it extremely difficult to assess the validity of many published OSL ages. In the discussions below, therefore, we have not recalculated or corrected any of the published OSL ages.

Dating of glacial successions throughout the HimalayanTibetan orogen during the 1990s was driven mainly by the desire to define the timing of glaciation in mountain regions throughout the world to test whether glaciers responded synchronously with the Northern Hemisphere ice sheets and between mountain regions This work was stimulated by Gillespie and Molnar (1995) who, based on evidence throughout the mountainous regions of the world, suggested that regional glaciations were asynchronous with each other, and that glaciers did not all reach their maximum extents at the same times as the high-latitude ice sheets, which was a common assumption at the time. Gillespie and Molnar (1995) further suggested that, even within Asia, advances from one region to another were asynchronous. Some likely reached their maximum extents early in the last glacial cycle, before the global Last Glacial Maximum (LGM) at ca. 18-25 ka). However, in 1995 the data for the Himalayan-Tibetan region were too sparse to demonstrate with confidence the degree of synchrony or asynchrony from region to region within Asia. Benn and Owen (1998), using newly published ages, were able to demonstrate that during the last glacial cycle glacial advances were indeed not synchronous throughout the Himalayan-Tibetan orogen. Rather, in some areas glaciers reached their maxima at the global LGM, whereas in others glaciers were most extensive at ca. 60-30 ka during Marine Isotope Stage (MIS) 3. Benn and Owen (1998) suggested that comparison of these data with palaeoclimatic records from adjacent regions showed that, on millennial timescales, Himalayan glacier fluctuations are controlled by variations 
in both the South Asian monsoon and the mid-latitude westerlies.

In addition to these two hypotheses, researchers needed a chronological framework to date glacial and associated landforms to test new paradigms in tectonics and geomorphology, such as the tectonic aneurysm and glacial buzzsaw models. This increased the application of geochronological methods to dating glacial successions.

The dating of Richards et al. (2000a,b) provided the first real attempt to test the palaeoclimate hypotheses in Asia. Their dating showed that glacial advances in Pakistan and Khumbu were more extensive in the earlier part of the last glacial cycle, but that glaciers did advance during the global LGM. However, their study was not geographically extensive enough to adequately test these hypotheses fully.

The development and application of TCN surface exposure dating throughout the 1990 s and early 2000s to glacial successions provided a means to test these hypotheses more adequately. Data from these studies are summarised in Fig. 3. Currently, there are $>800$ TCN surface exposure ages published in the literature for glacial and associated landforms in the Himalayan-Tibetan orogen. Most of the TCN surface exposure dating use ${ }^{10} \mathrm{Be}$ because it is by far the simplest chemical and physical system to understand and it is formed in quartz, which is extremely common in most Himalayan and Tibetan rocks. The number of TCN ages contrasts markedly with luminescence $(\sim 100)$ and radiocarbon $(\sim 100)$ ages for glacial deposits and landforms in the Himalayan-Tibetan orogen.

The first study that applied TCN surface exposure methods in the Himalayan-Tibetan orogen was undertaken by Phillips et al. (2000), who attempted to date the moraines around Nanga Parbat in northern Pakistan. Although their dating was somewhat limited (Richards et al., 2001), it suggested that a significant glacial advance occurred between ca. 60 and $30 \mathrm{ka}$, and that glaciers advanced during the early to middle Holocene. A plethora of papers following this work emerged and they included distant regions throughout the HimalayanTibetan orogen (Owen et al., 2001, 2002a,b, 2003a,b,c, 2005, 2006a,b; Schäfer et al., 2002; Finkel et al., 2003; Zech et al., 2003, 2005; Barnard et al., 2004a,b, 2006a,b; Meriaux et al., 2004; Chevalier et al., 2005; Abramowski et al., 2006; Seong et al., 2007, 2008a).

Owen et al. (2005) summarised the TCN studies and suggested that the regional patterns and timing of glaciation reflect temporal and spatial variability in the South Asian monsoon and, in particular, in regional precipitation gradients. They argued that in zones of greater aridity, the extent of glaciation has become increasingly restricted throughout the Quaternary, leading to the preservation of old ( $\gg 100 \mathrm{ka}$ ) glacial landforms. In contrast, in regions that are strongly influenced by the monsoon $\left(\gg 1600 \mathrm{~mm} \mathrm{a}^{-1}\right.$ ), they argued that the preservation potential of pre-Lateglacial moraine successions is generally extremely poor. This is possibly because Lateglacial and Holocene glacial advances may have been more extensive than earlier glaciations and hence may have destroyed any landform or sedimentary evidence of earlier glaciations. Furthermore, the intense denudation, mainly by fluvial and mass movement processes, which characterise these wetter environments, results in rapid erosion and re-sedimentation of glacial and associated landforms that contributes to their poor preservation potential. They showed that glacial advances could be broadly correlated (on timescales with a coarseness of several millennia) throughout the region, and that glaciers oscillated with a frequency that was similar to Northern Hemisphere millennia cycles.

Despite the vast application of TCN to defining the timing of glaciation, it is not yet possible to adequately determine whether glaciation is truly asynchronous throughout the region for the entire time for which ages are available. Two distinct sets of factors hinder our ability to interpret these chronologies. The first set of factors is geological and includes weathering, exhumation, prior exposure and shielding of the surface by snow and/or sediment. These generally reduce the concentration of TCNs, resulting in an underestimate of their true age. An exception to this general rule is prior exposure, which results in an overestimate of the true age. The net result of these processes can be a large spread in apparent exposure ages of individual boulders on a landform, such as a moraine, or in different positions on an extensive rock surface such as glacially eroded bedrock. To assess these effects, researchers usually collect multiple samples on a surface that they are dating. The presence of multiple boulders or surface samples having similar apparent ages is taken as evidence that the boulders were not derived from older surfaces and/or were not weathered or exhumed and hence the ages representative of the true age of the surface.

The second set of factors involves the calculation of the production rate of $\mathrm{TCN}$ s for the sampling location. This is dependent upon the cosmic ray flux, which has varied spatially and temporally in association with variations in the geomagnetic field intensity and atmospheric pressure throughout the Quaternary (Lal, 1991; Gosse and Phillips, 2001). Specifically, it is well documented from many independent proxy records that the Earth's geomagnetic field strength fluctuated considerably throughout the Quaternary (Ohno and Hamano, 1992; Guyodo and Valet, 1999; Yang et al., 2000). There is currently much debate regarding the appropriate scaling models and geomagnetic corrections for TCN production to calculate TCN ages (e.g. Pigati and Lifton, 2004; Staiger et al., 2007).

Unfortunately, the biggest uncertainty in scaling models is for low-latitude and high-altitude regions (Balco et al., 2008). Figure 5 shows the effects of using four different timedependent scaling models and geomagnetic corrections on ${ }^{10} \mathrm{Be}$ TCN ages for four distant areas in the Himalayan-Tibetan orogen. These were calculated using CRONUS Earth 2 (Balco et al., 2008; http://hess.ess.washington.edu/math/). The figures clearly show that there is up to $30 \%$ difference in apparent ages among scaling models over the last $70 \mathrm{ka}$. The biggest differences are between the time constant (with no correction for geomagnetic field variation) model of Lal (1991) and Stone (2000) and the other models. Differences among models vary by as much as $20 \%$, with the most significant differences occurring after ca. $20 \mathrm{ka}$. The general trend of these differences between scaling models is the same between the distant regions of Tibet, but the magnitude of the difference is more apparent for the Khumbu Himal, which is at the lowest latitude of any of the regions and reaches the highest elevations.

There is also a large variance in ages among scaling models for changes in altitude (Fig. 6). Differences in ages between scaling models can be as much as $20 \%$, the biggest being between the time constant model of Lal (1991) and Stone (2000) and the other models. This biggest difference is at an altitude of $\sim 2500 \mathrm{~m}$ a.s.l. Age differences of up to $12 \%$ are apparent between the time-dependent mode1s, and are most apparent above $\sim 4500 \mathrm{~m}$ a.s.l.

To complicate matters further, different studies have used different production rates and scaling models to calculate their TCN ages. Table 1 (Supporting Information) lists all the published ${ }^{10} \mathrm{Be}$ TCN ages for boulders on moraines and icepolished surfaces for the Himalayan-Tibetan orogen. To enable comparisons to be made between regions, we have recalculated all these data for the different scaling models using CRONUS Earth 2 calculator (http://hess.ess.washington.edu/ math/); these are listed next to the published ages in Table 1 

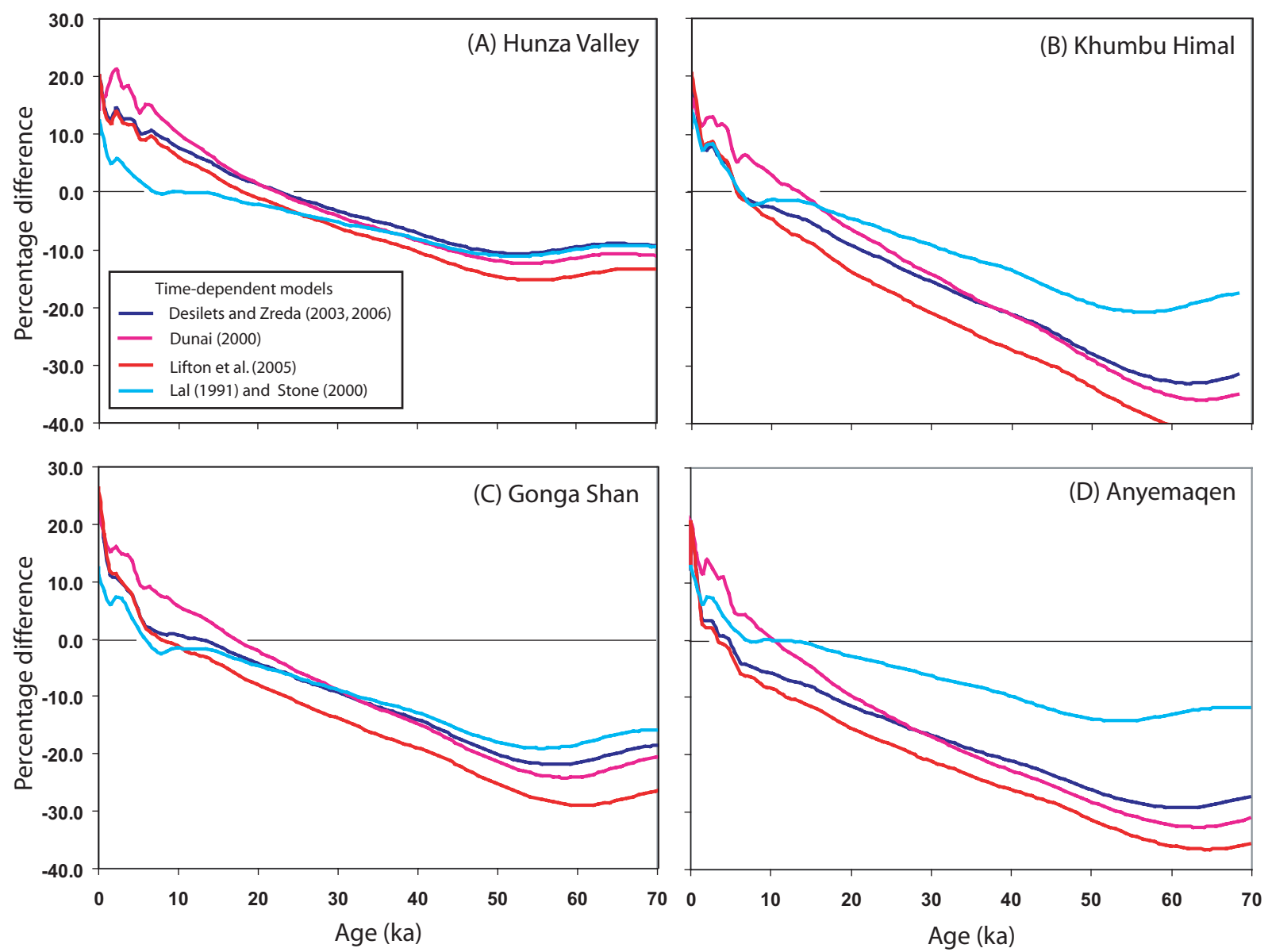

Figure 5 Percentage exposure age difference over the last 70 ka between time-constant (no correction for geomagnetic field variation) scaling method (Lal, 1991, and Stone, 2000; horizontal line, i.e. where $x=0$ ) and various time-varying scaling schemes for distant locations in the HimalayanTibet orogen (other curves). (A) Hunza valley at $36.46^{\circ} \mathrm{N}, 74.90^{\circ} \mathrm{E}, 2500 \mathrm{~m}$ a.s.I. (site of sample KK98-1 of Owen et al., 2002a). (B) Khumbu Himal at $27.89^{\circ} \mathrm{N}, 86.82^{\circ} \mathrm{E}, 4330 \mathrm{~m}$ a.s.I. (site of sample E5 of Finkel et al., 2003). (C) Gonga Shan at 29.57 $\mathrm{N}, 101.99^{\circ} \mathrm{E}, 3174 \mathrm{~m}$ a.s.l. (site of sample GS1 of Owen et al., 2005). (D) Anyemaqen at $34.89^{\circ} \mathrm{N}, 99.44^{\circ} \mathrm{E}, 4285 \mathrm{~m}$ a.s.I. (site of sample A1 of Owen et al., 2003a). The Lal (1991)-Stone (2000) timeconstant production rate at the location for (A) is 27.68 atoms $\mathrm{g}^{-1} \mathrm{a}^{-1}$ (spallation) and $0.439 \mathrm{atoms} \mathrm{g}^{-1} \mathrm{a}^{-1}$ (muons); for (B) is 63.05 atoms $\mathrm{g}^{-1} \mathrm{a}^{-1}$ (spallation) and 0.729 atoms $\mathrm{g}^{-1} \mathrm{a}^{-1}$ (muons); for (C) is 35.11 atoms g $\mathrm{a}^{-1}$ (spallation) and 0.534 atoms $\mathrm{g}^{-1} \mathrm{a}^{-1}$ (muons); and for (D) is 72.95 atoms g $\mathrm{a}^{-1}$ (spallation) and 0.715 atoms g $^{-1} \mathrm{a}^{-1}$ (muons)

(Supporting Information). The differences between the published ages and the newly calculated ages are considerable (up to $40 \%$ difference; Fig. 7 ).

To identify possible times of glacier advances, we have used probability density plots for the ${ }^{10} \mathrm{Be}$ ages for boulders on moraines and glacially polished rock surfaces for selected time slices (Fig. 8). We recognise that pooling all the ages incorporates boulders or glacially eroded rock surfaces that may have ages too great or too small to represent the true age of the glacial advance because of the geological problems highlighted above. However, the large number of ages (many hundreds) help provide an estimate of the pattern of timing of glaciation. Given the uncertainties between the different scaling models to calculate TCN ages we choose the timeconstant scaling model of Lal (1991) and Stone (2000). This does not take into account varied production of TCNs due to changes in the Earth's geomagnetic field. This approach allows us to directly compare regions. We recognise that the shape of these probability plots would vary if calculated using different scaling models. This would effectively skew the probability plots after ca. $20 \mathrm{ka}$ towards the older range end of the distribution by between a few to $20 \%$ of the age.

The probability plots shown in Fig. 8 demonstrate a decrease in sample frequency with increasing age. This is essentially a function of preservation, with younger landforms being better preserved, more common and less difficult to date. Hence there is more data for the late Quaternary.

Multiple peaks are apparent for most of the probability plots in Fig. 8. This supports the view that multiple glacier oscillations occurred throughout the Holocene (Fig. 8(A)). There is not a dominant peak for the global LGM centred on 21 ka (Fig. 8(A) and (B)). Rather, the dominant peak occurs in the Lateglacial and is centred round ca. 12-14 ka. This suggests that the Lateglacial glacial advance was more dominant than that of the global LGM and/or better preserved. Even given the uncertainties associated with the difference scaling models, a $20 \%$ underestimate of the TCN ages would still not allow the data to support a significant global LGM advance.

The probability plots for data for MIS 3 to MIS 5e (inset in Fig. 8(B)) show peaks in the data centred on ca. $26 \mathrm{ka}$ and ca. $47 \mathrm{ka}$ (the ca. $26 \mathrm{ka}$ peak is not apparent when the data are plotted from 0 to $115 \mathrm{ka}$ as the younger ages skew the population). The probability plot is skewed towards the young end of the distribution, which is likely a function of the preferential sampling of younger landforms. The data support the view that significant glacial advances occurred during MIS 3 , with the possibility of multiple advances occurring during the earlier part of the last glacial. 


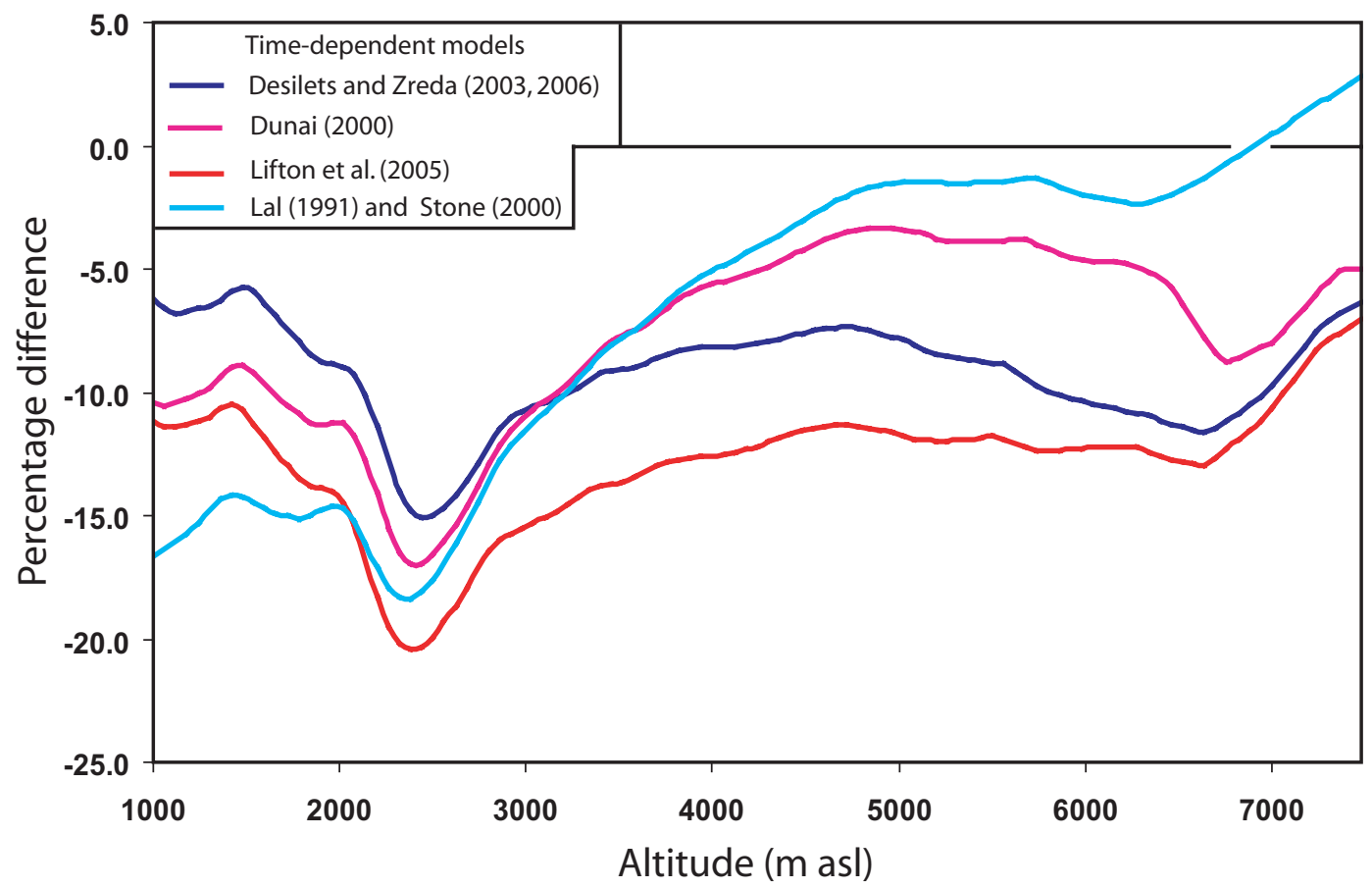

Figure 6 Percentage exposure age difference between time-constant (no correction for geomagnetic field variation) scaling method (Lal, 1991, and Stone, 2000; horizontal line, i.e. where $x=0$ ) and various time-varying scaling schemes (other curves) for altitudes ranging from 1000 to $7500 \mathrm{~m}$ a.s.I. for the Khumbu Himal (at $27.89^{\circ} \mathrm{N}, 86.82^{\circ} \mathrm{E}$ based on sample E5 of Finkel et al., 2003)

Grouping the data by time intervals does not indicate any regional differences. The above conclusions might be spurious because the pooled ages would not allow us to see whether glaciation was regionally asynchronous. To examine this problem the TCN ages are plotted per major climatic region throughout the Himalayan-Tibetan orogen (Fig. 9). The probability plots support most of the general comments highlighted for the data for the whole region. This includes a decrease in frequency of TCN ages with age, with the exception being for the westernmost Himalaya-Tibet orogen (Turkestan, Alay and South Alichur Ranges, and the Ailuitek Pass), where no Holocene samples have been collected as part of the sampling strategy. The data also show multiple peaks for the Holocene in all regions (except for the westernmost Himalayan-Tibetan orogen; Fig. 9). Furthermore, there are significant Lateglacial peaks in all regions except for the westernmost

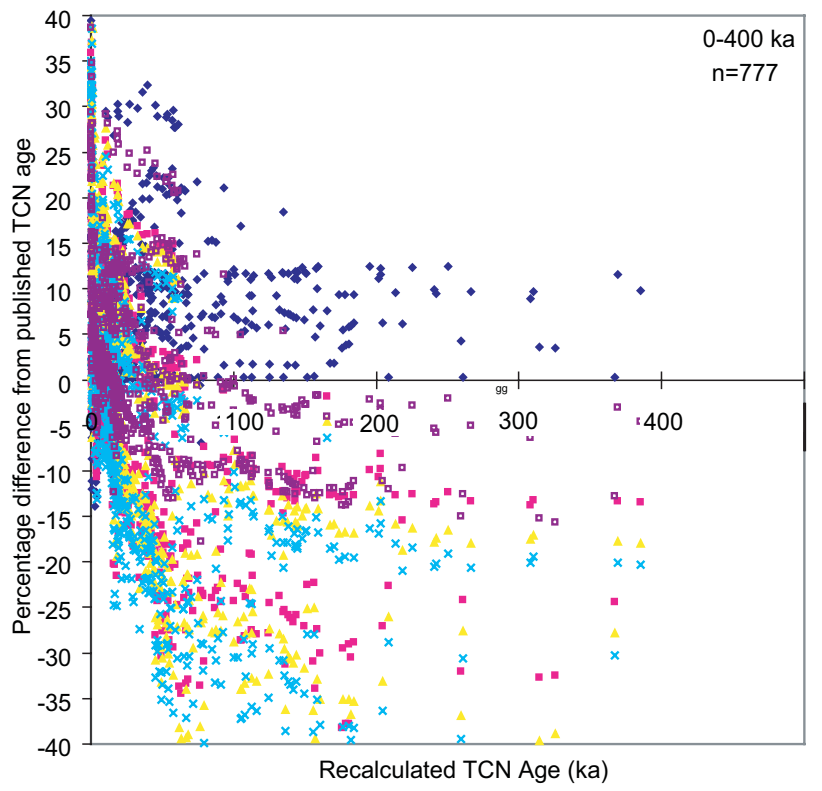

- Lal (1991)/Stone (2000)(time independent) - Desilets and Zreda $(2003,2006)$

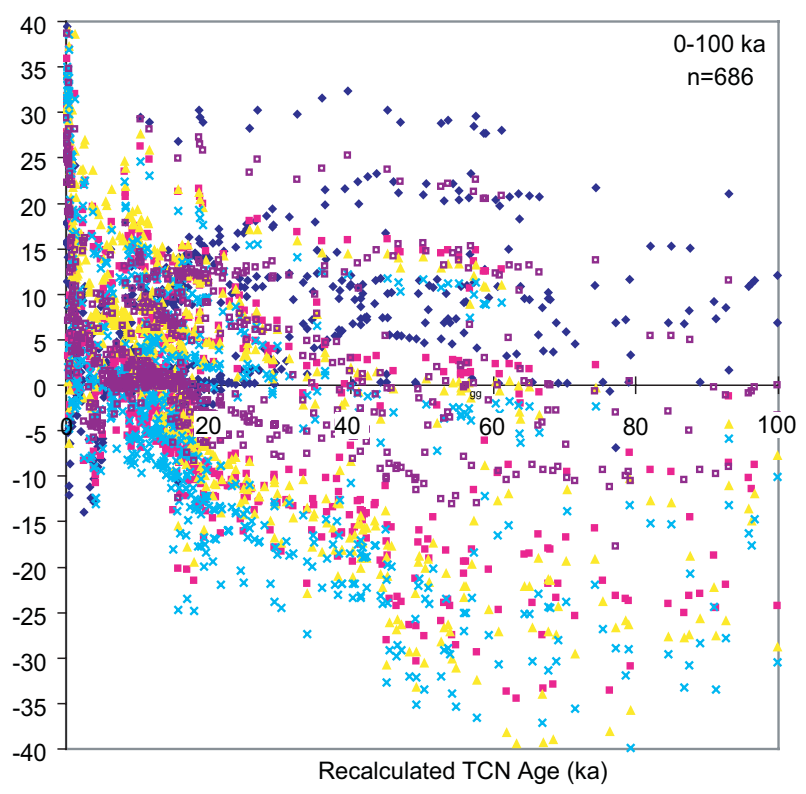

Dunai (2000) $\times$ Lifton et al. (2005) $\quad$ L Lal (1991)/Stone (2000)(time dependent)

Figure 7 Percentage difference between published ages and ages recalculated using different scaling schemes for (A) all ages (0-500 ka) and (B) the last 100 ka (data from Phillips et al., 2000; Owen et al., 2001, 2002a,c, 2003a,b,c, 2005, 2006a,b; Schäfer et al., 2002; Finkel et al., 2003; Zech et al., 2003, 2005; Barnard et al., 2004a,b, 2006a,b; Meriaux et al., 2004; Chevalier et al., 2005; Abramowski et al., 2006; Colgan et al., 2006; Seong et al., 2007, 2008a) 

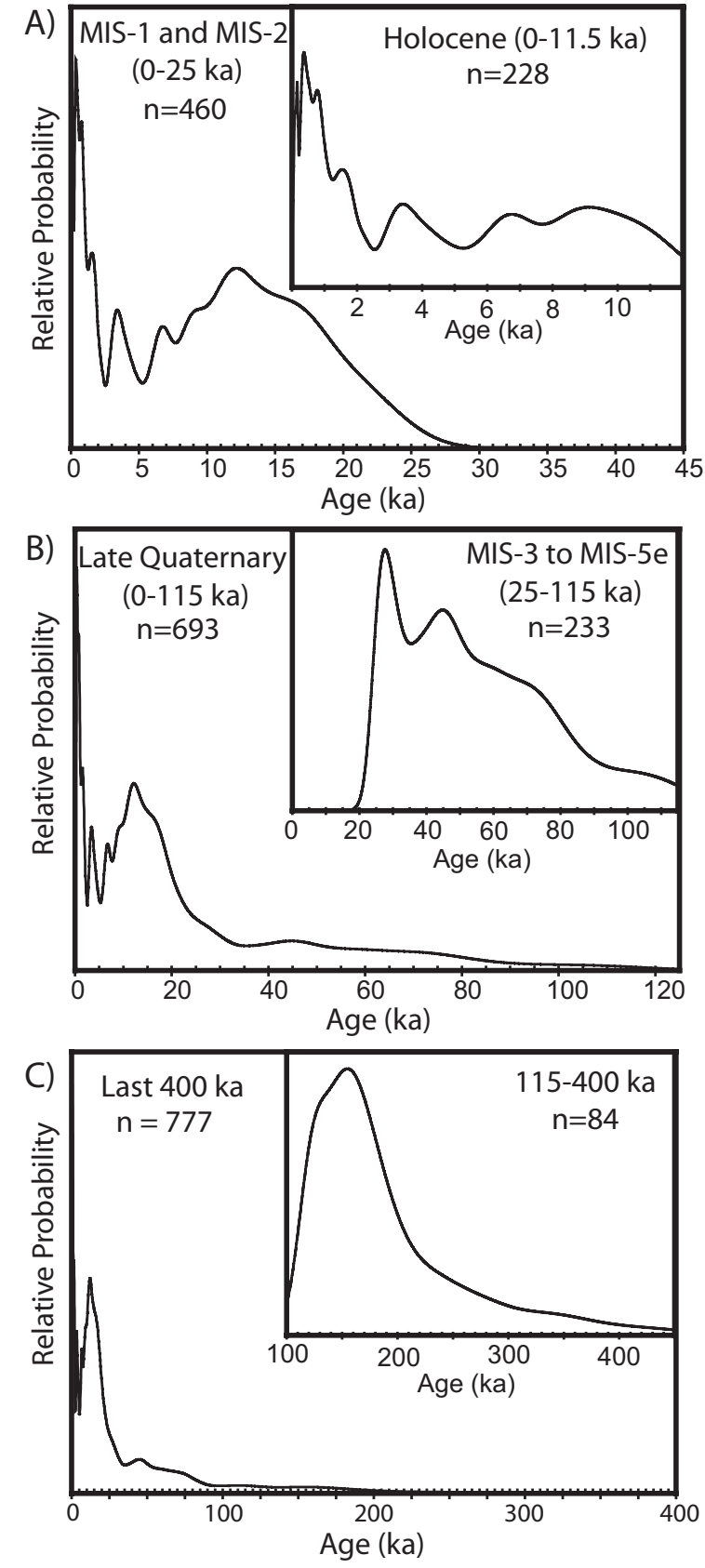

Figure 8 Probability density functions of TCN ${ }^{10}$ Be ages for all published data from the Himalayan-Tibetan orogen for (A) MIS 1 and MIS 2 and (inset) the Holocene, (B) late Quaternary and (inset) MIS 3 and MIS $5 \mathrm{e}$, and (C) last $400 \mathrm{ka}$ and (inset) 115-450 ka (data from Phillips et al., 2000; Owen et al., 2001, 2002a,c, 2003a,b,c, 2005, 2006a,b; Schäfer et al., 2002; Finkel et al., 2003; Zech et al., 2003, 2005; Barnard et al., 2004a,b, 2006a,b; Meriaux et al., 2004; Chevalier et al., 2005; Abramowski et al., 2006; Colgan et al., 2006; Seong et al., 2007, 2008a). The number of samples used to produce each probability plot is indicated by ' $\mathrm{n}$ '

Himalayan-Tibetan orogen (Fig. 9(B)). The westernmost Himalayan-Tibetan orogen is the only region where there is a notable peak for the global LGM. Similarly, all regions except the westernmost Himalayan-Tibetan orogen have significant peaks during MIS-3 (although the monsoon-influenced Himalaya is subdued by the large number of young ages), whereas the westernmost Himalayan-Tibetan orogen is the only region with a dominant peak during MIS 4. Even with differences in ages due to the different scaling models, the peaks would still fall within MIS 3 and MIS 4 for these respective regions. These data suggest that the westernmost Himalayan-Tibetan orogen is behaving differently from the other regions. This region is most
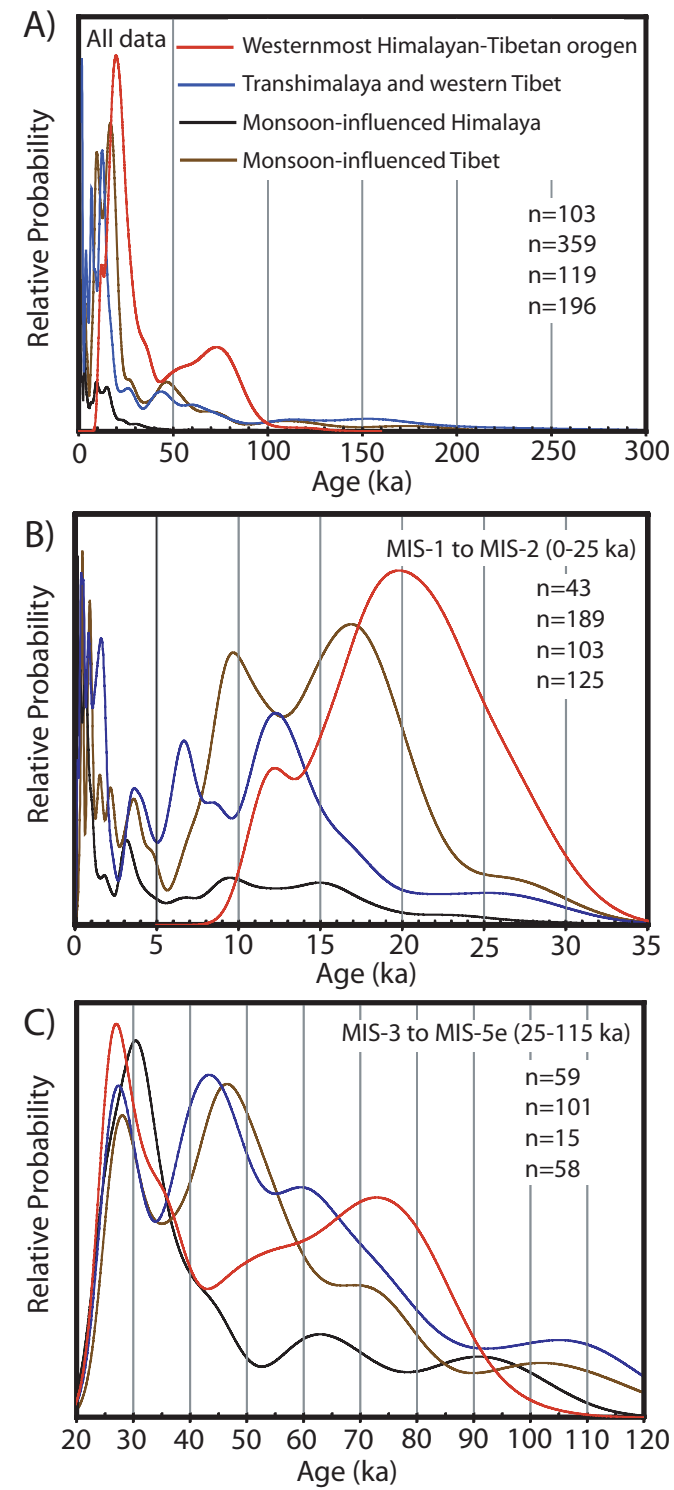

Figure 9 Probability density functions of $\mathrm{TCN}{ }^{10} \mathrm{Be}$ ages for all published data from the Himalayan-Tibetan orogen plotted for each major climatic region. (A) All published data; (B) MIS 1 and MIS 2; and (C) MIS 3 to MIS 5e (data from Phillips et al., 2000; Owen et al., 2001, 2002a,b, 2003a,b,c, 2005, 2006a,b; Schäfer et al., 2002; Finkel et al., 2003; Zech et al., 2003, 2005; Barnard et al., 2004a,b, 2006a,b; Meriaux et al., 2004; Chevalier et al., 2005; Abramowski et al., 2006; Colgan et al., 2006; Seong et al., 2007, 2008a). The number of samples used to produce each probability plot is indicated by ' $n$ ' in the order of the regions shown in the legend of part (A). Fig. 3 shows the areas included in each region

influenced by the mid-latitude westerlies and has little influence from the south Asian monsoon.

There are subtle variations in the data between the other regions, but given the errors associated with pooling data we are reluctant to ascribe much significance to small differences (Fig. 9(B) and (C)). Geochemical data from Tibetan and Himalayan ice cores show that there have been numerous glacier oscillations on millennial timescales throughout the Last Glacial (Thompson et al., 1989, 1997; Thompson, 2000). The multiple peaks in the probability plots for the TCN ages likely reflect many of these glacier oscillations. The possibility of numerous glacier advances also complicates correlations between regions based on TCN dating, especially because the TCN dating method is relatively imprecise ( $~ 8 \%$ systematic error; Balco et al., 2008). A detailed interpretation of the interregional variability therefore requires more comprehensive 
studies of individual regions using multiple dating methods. Unfortunately, there are few areas where comprehensive geochronological studies have been undertaken. We recognise three main areas - the Hunza valley in the Karakoram, Khumbu Himal and the Anyemaqen and Nianbaoyeze in NE Tibet - that provide the possibility of beginning to define the timing of glaciation and test regional correlations more accurately. These will be described in the next section.

\section{Key areas}

Data from three of the most detailed studied regions have been reassessed to evaluate the Quaternary glacial record in the Himalayan-Tibetan orogen more fully. We present the original data and recalculate TCN ages using new production rates for these regions (Figs 10,11 and 12).

The first of these regions, the Hunza valley, has a long history of study, which began in the late 1970s as a consequence of the construction of the Karakoram Highway, which links northern Pakistan with China across the Himalaya and Karakoram. As a consequence, numerous Chinese publications were produced on the glacial geomorphology and history, which culminated in the International Karakoram Project in 1980 involving Pakistani, Chinese and British scientists (Batura Glacier Investigation Group, 1976, 1979; Zhang and Shi, 1980; Miller, 1984). More detailed geochronological studies were undertaken by Owen et al. (2002a) and Spencer and Owen (2004), who used TCN and OSL methods, respectively. These data are graphically presented in Fig. 10. The probability plots for the recalculated TCN ages make the glacial stages a little older by a few thousand years as compared to the original data. In combination with the OSL ages of Spencer and Owen (2004), however, the timing of glaciation is similar to that suggested in Owen et al. (2002a) (bracketed by the thick colour bars in Fig. 10). Despite the disagreement between the ages presented in these studies, the moraine ages are still assigned to the same glacial times as presented by Owen et al. (2002a). They argued, for example, that glaciers were responding both to changes in insolation-controlled monsoon precipitation that allowed glaciers to advance during the early Holocene and MIS 3, and Northern Hemisphere cooling that allowed glaciers to advance during the global LGM.

Figure 10 shows Prell and Kutzbach's (1987) simulated monsoon pressure index for the Indian Ocean and simulated changes in precipitation in southern Asia together with variations in Northern Hemisphere low-latitude solar radiation as a proxy for changing precipitation in the region to assess the likely connections between the monsoon and glaciation. Furthermore, the Heinrich events for the past $70 \mathrm{ka}$ (Bond et al., 1992) are plotted as a proxy for changes in the Northern Hemisphere ice sheets and oceans to assess correlations and connections. Comparisons with both datasets are rather tentative at present and the relative roles and connections with the different climate systems are difficult to resolve.

The Khumbu Himal, south of Mount Everest, is the second key area. Numerous studies have been undertaken on the Quaternary glacial and associated landforms in this region (Benedict, 1976; Iwata, 1976; Fushimi, 1977, 1978; Müller, 1980; van Williams, 1983; Richards et al., 2000b; Finkel et al., 2003; Barnard et al., 2006a). The earliest geochronological studies involved radiocarbon dating of late Holocene moraines (Benedict, 1976; Fushimi, 1978; Müller, 1980). This was followed by OSL dating of late Quaternary moraines by Richards et al. (2000b), who showed that glaciers advanced during the global LGM (18-25 ka), the early Holocene ( 10 ka) and the late Holocene $(1-2 \mathrm{ka})$. These advances were confirmed by Finkel et al. (2003) using ${ }^{10} \mathrm{Be}$ TCN dating methods. Finkel et al. (2003) were also able to define the ages of a Neoglacial advance at $\sim 3.6 \mathrm{ka}$, a Lateglacial advance (15$16 \mathrm{ka})$ and two advances during MIS 3.

The chronology and dating of Finkel et al. (2003) and Richards et al. (2000b) are plotted on Fig. 11 together with probability plots for the recalculated TCN ages. The OSL and the original TCN ages agree reasonably well, but the TCN are generally younger by a few hundred years. This would be expected since the sediment that was dated using OSL methods should pre-date the overlaying boulders that were dated using TCN methods. The probability plots suggest the TCN ages should be a little older then those published in Finkel et al. (2003); however, they still support the view that glaciers advanced during MIS 3, the global LGM, Lateglacial, early Holocene, Neoglacial and late Holocene. A comparison of these data with monsoon intensity (Fig. 11(E)) supports the view that glaciers advance during times of increased insolation. These were times when moisture delivered by an active South Asian summer monsoon was enhanced and provided snow to create positive glacier mass balances allowing glaciers to advance. Furthermore, increased cloudiness during monsoon could also help contribute significantly to positive glacier mass balances (Rupper, 2007). However, glaciers may also have been influenced by cooling cycles during the late Quaternary, for example during the global LGM.

Considerable attention has been paid to the glacial chronologies at the NE margin of Tibet. The Anyemaqen and the Nianbaoyeze are two significant massifs in this region and form the third key study area. These massifs have been studied in detail by Wang (1987) and Lehmkuhl and Lui (1994). TCN and OSL dating was undertaken by Owen et al. (2003a) to define the timing of glaciation. They showed that glacial advances occurred during MIS 3 (ca. 30-55 ka), MIS 2 (ca. 12 $25 \mathrm{ka})$ and early Holocene ( 10 ka). Recalculated TCN ages are presented as probability plots for the regions in Fig. 12. This shows that there is a significant MIS 3 advance, and Lateglacial and early Holocene advance. The glacial advances would have still dated to the early Holocene, Lateglacial and MIS 3 regardless of the scaling model used to calculate the ages. This indicates and supports the view of Owen et al. (2003a) that glaciers in this region are influenced by the South Asian monsoon. The maximum extent of glaciation occurred early in the last glacial cycle (MIS 3) during a time of increased insolation when the monsoon was intensified and supplied abundant precipitation, as snow at high altitude, to feed highaltitude glaciers. This indicates that precipitation, as snow is fundamental in controlling glaciation in these regions.

\section{ELAs}

Reconstructions of the timing and extent of glaciation are used as a proxy for palaeoclimate change. The most commonly applied technique that is used involves the reconstruction and use of former ELAs and ELA depressions ( $\triangle$ ELAs) relative to the present. The reconstructed $\Delta$ ELAs are used to estimate past temperature and/or precipitation changes and to assess regional climatic gradients and variability. Benn and Lehmkuhl (2000), Owen and Benn (2005) and Benn et al. (2003) describe how reconstructing former ELAs and $\triangle$ ELAs can be problematic in high mountain regions, specifically the Himalayan-Tibetan orogen. These problems occur because of extreme topographic 


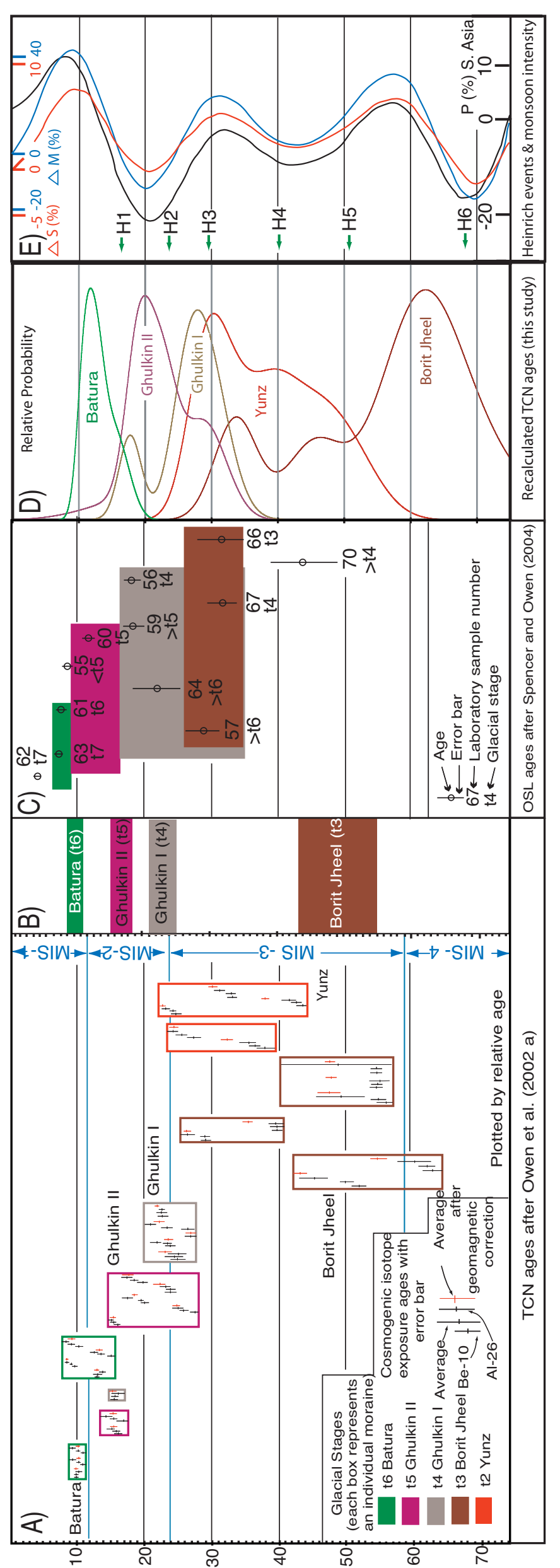

(еу) әщ!!

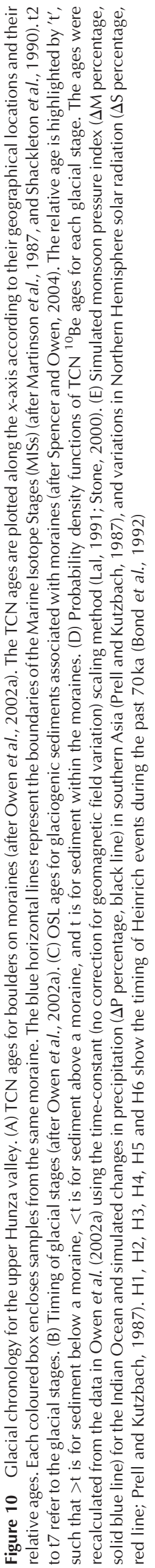

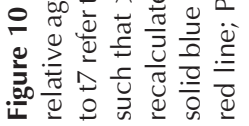




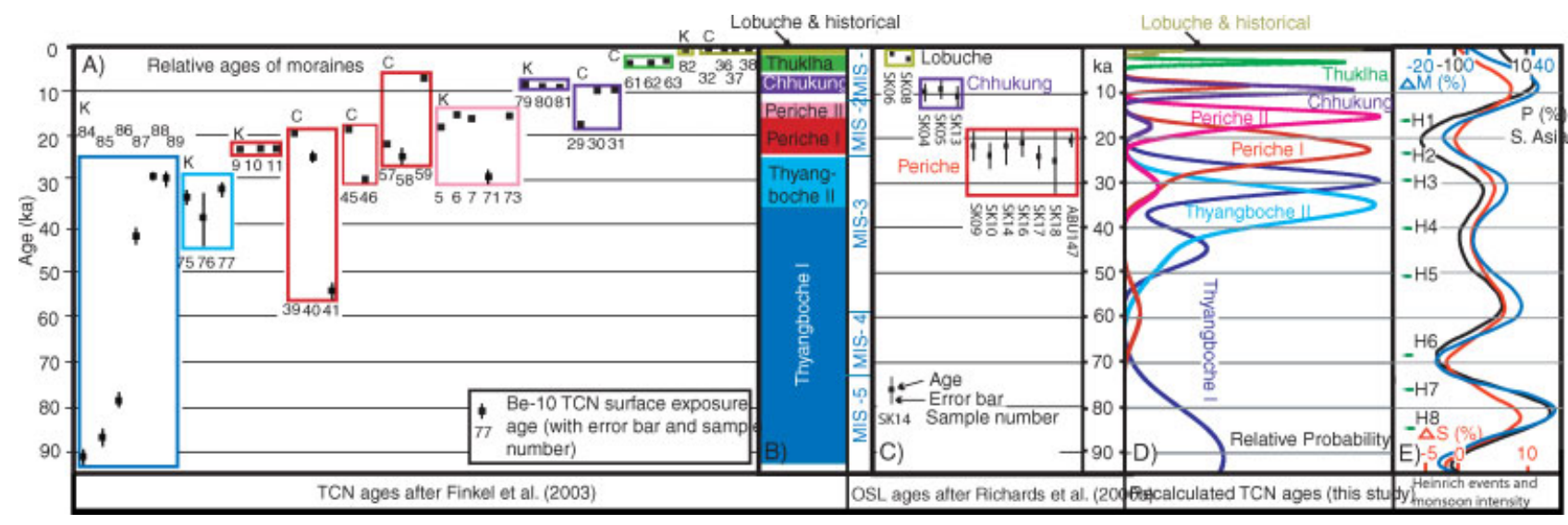

Figure 11 Glacial chronology for the Khumbu Himal. (A) TCN ages for boulders on moraines (after Finkel et al., 2003). The TCN ages are plotted along the $x$-axis according to their relative ages and geographical locations (C, Chhukung; K, Periche to Khumbu Glacier). Each coloured box encloses samples from the same moraine. (B) Timing of glacial stages (after Finkel et al., 2003). The Marine Isotope Stages (MIS) are taken from Martinson et al. (1987) and Shackleton et al. (1990). (C) OSL ages for glaciogenic sediments associated with moraines (after Richards et al., 2000b). The coloured boxes enclose OSL ages for sediment within the moraines for three glacial stages. (D) Probability density functions of TCN ${ }^{10}$ Be ages for each glacial stage. The ages were recalculated from the data in Finkel et al. (2003) using the time-constant scaling method (Lal, 1991; Stone, 2000). (E) Simulated monsoon pressure index ( $\Delta \mathrm{M}$ percentage, solid blue line) for the Indian Ocean and simulated changes in precipitation ( $\Delta \mathrm{P}$ percentage, black line) in southern Asia (Prell and Kutzbach, 1987), and variations in Northern Hemisphere solar radiation ( $\Delta$ S percentage, red line; Prell and Kutzbach, 1987). H1, H2, $\mathrm{H} 3, \mathrm{H} 4, \mathrm{H} 5, \mathrm{H} 6, \mathrm{H} 7$ and $\mathrm{H} 8$ show the timing of Heinrich events during the past 90 ka (Bond et al., 1992)

controls on glacier mass balance, the abundance of supraglacial debris cover and microclimatic variability, which, in combination, complicate the relationship between climate and glacier extent.

Owen and Benn (2005) summarised the current knowledge on contemporary and past ELAs for glaciers throughout the Himalayan-Tibetan orogen. They highlighted the considerable regional variation, which is the result of the influence of the two major climatic systems, the mid-latitude westerlies and the South Asian summer monsoon, plus the influence of strong topographic controls. Furthermore, there may be considerable local variability as highlighted by Sharma and Owen (1996) for the Garhwal Himalaya and Seong et al., (2008b) for Muztag Ata and Kongur Shan.

Owen and Benn (2005) argue that even though there have been numerous studies of ELAs throughout the Himalayan-

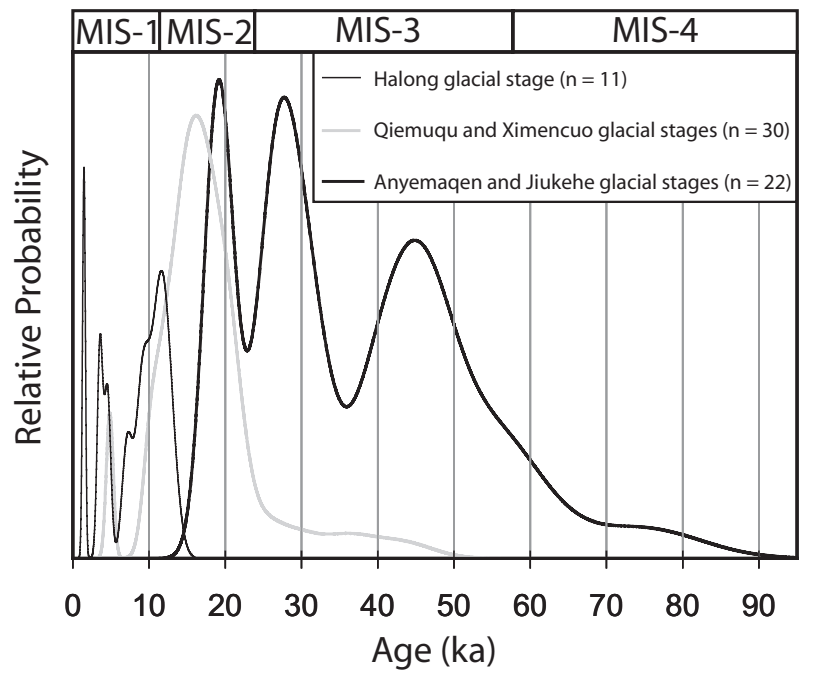

Figure 12 Probability density functions of $\mathrm{TCN}{ }^{10} \mathrm{Be}$ ages for glacial stages in the Anyemaqen and Nianbaoyeze of NE Tibet. The ages were recalculated from the data in Owen et al. (2003a) using the timeconstant scaling method (Lal, 1991; Stone, 2000). The Marine Isotope Stages (MISs) are taken from Martinson et al. (1987) and Shackleton et al. (1990)
Tibetan orogen, the methods for reconstructing former ELAs vary considerably between studies. Moreover, they emphasised that many of the methods that have been used are not applicable for these high-altitude glaciers. Furthermore, they showed that few of the reconstructions of former glaciers and their $\triangle$ ELA have any chronological control. Therefore regional comparisons of past ELAs like those presented by Shi (2002) do not fully represent the nature of glaciation because of the poor temporal framework and problematic methodologies. They do, however, provide an overview of the likely regional variation of $\Delta$ ELAs. Owen and Benn (2005) recognised only two locations, the Hunza valley and the Khumbu Himal, where glaciers of the global LGM have been accurately dated (Fig. 13). They calculated ELAs for these regions and showed that $\Delta$ ELAs were considerably less ( 200-300 $\mathrm{m}$ in the Khumbu and $\sim \leq 100 \mathrm{~m}$ for the Batura Glacier; Fig. 13(B) and (C)) than had been previously estimated for the global LGM in these regions $(\gg 500 \mathrm{~m})$.

In summary, present studies do not provide an adequate assessment of $\Delta$ ELAs for the Quaternary throughout the Himalayan-Tibetan orogen. As a consequence, temperatures and/or precipitation changes have yet to be quantified for the region.

\section{Summary}

The timing and extent of glaciation throughout the HimalayanTibetan orogen are poorly defined despite the importance of this region for geological studies and the economies of the countries that border its mountains. New technologies, including remote sensing and geochronology, are rapidly helping us to resolve the nature and dynamics of glaciation throughout the region. In particular, the broad patterns of the maximum extent of late Quaternary glaciation are beginning to be resolved. Figure 4(D) provides the best available estimate for the timing of the maximum extent of glaciation across the region, but even after measurement of $>1000 \mathrm{TCN}, \mathrm{OSL}$ and radiocarbon dates it is still not known conclusively whether the extent of maximum glaciation was reached at the same time. 

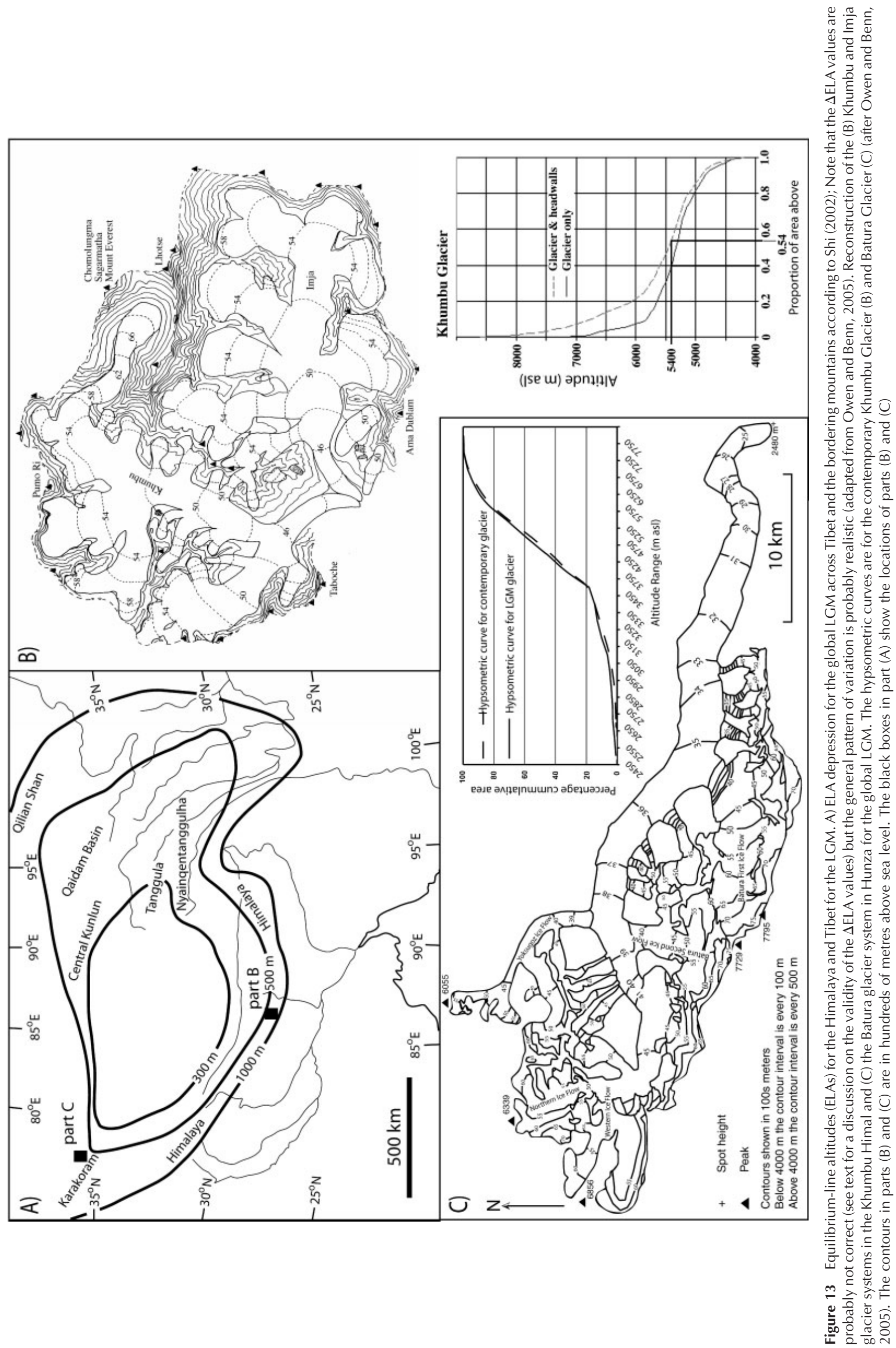
Detailed study areas provide important insights into testing these reconstructions, but they suggest considerable variations in the extent of glaciation during a specific glacial time between adjacent regions. This is best illustrated in northern Pakistan and northern India, where during the Lateglacial glaciers advanced more than $50 \mathrm{~km}$ in the $\mathrm{K} 2$ region of the Central Karakoram and Lahul Himalaya, but in the adjacent regions of the Hunza valley and Ladakh the glaciers advanced only a few kilometres beyond their current positions.

The timing of many of these glacial advances is poorly defined because of the lack of organic material needed for radiocarbon dating, the standard geochronological tool of glacial geomorphologists. However, newly developing OSL and TCN methods are helping to expand the chronologies throughout the region. These technologies allow broad correlations on Milankovitch timescales to be made, but are rife with methodological problems. With OSL dating, for example, partial bleaching and changes in dose rates over time can result in large errors. TCN dating can also be problematic, particularly with regard to the uncertainty associated with scaling models to determine ages, and the geological problems associated with preserving stable surfaces in active mountains.

Recalculating all the TCN ages for moraine boulders and glacially eroded surfaces throughout the Himalayan-Tibetan region allows broad statements to be made regarding the synchroneity of glaciation. In essence, glaciers throughout monsoon-influenced Tibet and the Himalaya and the Transhimalaya appear to respond in a similar fashion to changes in monsoon-driven and Northern Hemisphere cooling cycles alone. In contrast, glaciers in the far western regions of the Himalayan-Tibetan orogen are asynchronous with the other regions and appear to be dominantly controlled by the Northern Hemisphere cooling cycles.

Quantifying the magnitude of climate change from glacial geological evidence is challenging. The standard methods using ELAs can be problematic for the steep and debris-mantled glaciers in mountains. Nevertheless, broad patterns of local and regional variability can be established and are helping to examine changes in climatic gradients over time.

In conclusion, we stress the importance of developing a modern framework for the geomorphic and sedimentological analysis of glaciogenic sediments and landforms in high mountain environments for the accurate reconstruction of former glaciers and highlight the problems of dating glacial successions. Furthermore, we encourage programs for numerical dating in critical regions that apply multiple dating methods.

Acknowledgements We thank Tim Phillips for drafting Fig. 4, and the National Science Foundation for funding a workshop entitled 'Timing and nature of mountain glaciation, from High Asia to the World Exploring aspects of climate change, glaciation, and landscape evolution', under grant EAR0640378, where much of this paper was discussed. Special thanks to Alan Gillespie and Arjen Stroeven for their constructive and very detailed review of this paper. Thanks to Jason Dortch for comments on the revised manuscript.

\section{References}

Abramowski U, Bergau A, Seebach D, Zech R, Glaser B, Sosin P, Kubik PW, Zech W. 2006. Pleistocene glaciations of Central Asia: results from $10 B$ e surface exposure ages of erratic boulders from the Pamir (Tajikistan) and the Alay-Turkestan range (Kyrgyzstan). Quaternary Science Reviews 25: 1080-1096.
Ageta Y, Higuchi K. 1984. Estimation of mass balance components of a summer-accumulation type glacier in the Nepal Himalaya. Geografiska Annaler 66A: 249-255.

Ageta Y, Kadota T. 1992. Predictions of changes of glacier mass balance in the Nepal Himalaya and Tibetan Plateau: a case study of air temperature increase for three glaciers. Annals of Glaciology 16: 8994.

Balco G, Stone JO, Lifton NA, Dunai TJ. 2008. A complete and easily accessible means of calculating surface exposure ages or erosion rates from 10Be and 26Al measurements. Quaternary Geochronology 8: 174-195.

Barnard PL, Owen LA, Finkel RC. 2004a. Style and timing of glacial and paraglacial sedimentation in a monsoonal influenced high Himalayan environment, the upper Bhagirathi Valley, Garhwal Himalaya. Sedimentary Geology 165: 199-221.

Barnard PL, Owen LA, Sharma MC, Finkel RC. 2004b. Late Quaternary landscape evolution of a monsoon-influenced high Himalayan valley, Gori Ganga, Nanda Devi, NE Garhwal. Geomorphology 61: 91110.

Barnard PL, Owen LA, Finkel RC. 2006a. Quaternary fans and terraces in the Khumbu Himal south of Mount Everest: their characteristics, age and formation. Journal of Geological Society of London 163: 383-399.

Barnard PL, Owen LA, Finkel RC, Asahi K. 2006b. Landscape response to deglaciation; 1 ; in a high relief, monsoon-influenced alpine environment, Langtang Himal, Nepal. Quaternary Science Reviews 25: 2162-2176.

Barry RG, Chorley RJ. 2003. Atmosphere, Weather, and Climate, (8th edn). Routledge: London.

Batura Glacier Investigation Group. 1976. Investigation report on the Batura glacier in the Karakoram Mountains, the Islamic Republic of Pakistan (1974-1975). Batura Investigation Group, Engineering Headquarters, Peking.

Batura Glacier Investigation Group. 1979. The Batura glacier in the Karakoram Mountains. Scientia Sinica 22: 281-293.

Bäumler R, Madhikermi DP, Zech W. 1997. Fine silt and clay mineralogical changes of a soil chronosequence in the Langtang Valley (Central Nepal). Zeitschrift für Pflanzenernährung und Bodenkunde 160: $353-363$.

Benedict JB. 1976. Khumbu glacier series, Nepal. Radiocarbon 18: $177-178$.

Benn DI, Lehmkuhl F. 2000. Mass balance and equilibrium-line altitudes of glaciers in high mountain environments. Quaternary International 65/66: 15-29.

Benn DI, Owen LA. 1998. The role of the Indian summer monsoon and the mid-latitude westerlies in Himalayan glaciation: review and speculative discussion. Journal of the Geological Society 155: 353-363.

Benn DI, Owen LA. 2002. Himalayan glacial sedimentary environments: a framework for reconstructing and dating former glacial extents in high mountain regions. Quaternary International 97/98: $3-26$.

Benn DI, Owen LA, Osmaston HA, Seltzer GO, Porter CS, Mark B. 2003. Reconstruction of equilibrium-line altitudes for tropical and sub-tropical glaciers. Quaternary International 138/139: 8-21.

Bond G, Heinrich H, Broecker W, Labeyrie L, McManus J, Andrews J, Huon S, Jantschik R, Clasen S, Simet C, Tedesco K, Klas M, Bonani G, Ivy S. 1992. Evidence for massive discharges of icebergs into the North Atlantic during the last glacial period. Nature 360: 245-249.

Brozovic N, Burbank DW, Meigs AJ. 1997. Climatic limits on landscape development in the northwestern Himalaya. Science 276: 571-574.

Burbank DW, Kang JC. 1991. Relative dating of Quaternary moraines, Rongbuk Valley, Mount Everest, Tibet: implications for an Ice Sheet on the Tibetan Plateau. Quaternary Research 36: 1-18.

Bush ABG. 2000. A positive climatic feedback mechanism for Himalayan glaciation. Quaternary International 65/66: 3-13.

Bush ABG. 2002. A comparison of simulated monsoon circulations and snow accumulation in Asia during the mid-Holocene and at the Last Glacial Maximum. Global and Planetary Change 32: 331-347.

Chevalier M-L, Ryerson FJ, Tapponnier P, Finkel RC, Van Der Woerd J, Haibing L, Qing L. 2005. Slip-rate measurements on the Karakoram Fault may imply secular variations in fault motion. Science 307: 411414. 
Colgan PM, Munroe JS, Zhou S. 2006. Cosmogenic radionuclide evidence for the limited extent of last glacial maximum glaciers in the Tanggula Shan of the central Tibetan Plateau. Quaternary Research 65: 336-339.

Conway WM. 1894. Climbing and Exploration in the KarakoramHimalayas. Fisher-Unwin: London.

Cunningham A. 1854. Ladakh, Physical, Statistical, Historical, (reprinted 1970). Sagar: New Delhi.

Dainelli G. 1922. Studi sul glaciale Spedizone Italian de Filippi nell' Himalaia, Caracorume Turchestan/Cinese (1913-1914), Ser II, 3. Zanichelli: Bologna.

Dainelli G. 1934. Studi sul Glaciale: Spedizone Italian de Filippi nel'Himalaia, Caracorum e Turchestan Cinese (1913-1914), Ser. II., 3: Zanichelli: Bologna.

Dainelli G. 1935. La Series dei Terreni: Spedizione Ilaliana De Fillippi nell'Himalaia, Caracorum e Turchestan Chinese (1913-1914), Ser. II, 2: Zanichelli: Bologna.

DeMets C, Gordon RG, Argus DF, Stein S. 1994. Effects of recent revisions to the geomagnetic reversal time scale on estimates of current plate motion. Geophysical Research Letters 21: 2191-2194.

Derbyshire E. 1982. Glacier regime and glacial sediment facies: a hypothetical framework for the Qinghai-Xizang Plateau. In Proceedings of Symposium on Qinghai-Xizang (Tibet) Plateau, Beijing, China, Vol. 2. Geological and Ecological studies of Qinghai-Xizang Plateau. Science Press: Beijing; 1649-1656.

Derbyshire E. 1983. The Lushan dilemma: Pleistocene glaciation south of the ChangJiang (Yangste River). Zeitschrift für Geomorphologie 27: 445-471.

Derbyshire E. 1987. A history of the glacial stratigraphy in China. Quaternary Science Reviews 6: 301-314.

Derbyshire E, Owen LA. 1990. Quaternary alluvial fans in the Karakoram Mountains. In Alluvial Fans: A Field Approach, Rachocki $\mathrm{AH}$ Church M (eds). Wiley: Chichester; 27-53.

Derbyshire E, Li J, Perrott FA, Xu S, Waters RS. 1984. Quaternary glacial history of the Hunza valley Karakoram Mountains, Pakistan. In International Karakoram Project, Miller K (ed.). Cambridge University Press: Cambridge, UK; 456-495.

Derbyshire E, Shi Y, Li J, Zheng B, Li S, Wang J. 1991. Quaternary glaciation of Tibet: the geological evidence. Quaternary Science Reviews 10: 485-510.

Desilets D, Zreda M. 2003. Spatial and temporal distribution of secondary cosmic-ray nucleon intensities and applications to in situ cosmogenic dating. Earth and Planetary Science Letters 206: 21-42.

Desilets D, Zreda M. 2006. Elevation dependence of cosmogenic 36Cl production in Hawaiian lava flows. Earth and Planetary Science Letters 246: 277-287.

De Terra H, Paterson TT. 1939. Studies on the Ice Age in India and associated human cultures. Publication 493, Carnegie Institute of Washington.

Dey B, Bhanu Khumar OSRU. 1982. An apparent relationship between Eurasian spring snow cover and the advance period of the Indian summer monsoon. Journal of Applied Meteorology 21: 1929-1923.

Dey B, Kathuria SN, Bhanu Khumar OSRU. 1985. Himalayan summer snow cover and withdrawal of the Indian summer monsoon. Journal of Climatology and Applied Meteorology 24: 865-868.

Dickson RR. . Eurasian snow cover versus Indian monsoon rainfall: an extension of the Hahn-Shukla results. Journal of Climatology and Applied Meteorology 23: 171-173.

Drew F. 1873. Alluvial and lacustrine deposits and glacial records of the upper Indus basin. Part 1: Alluvial deposits. Geological Society of London Quarterly Journal 29: 449-471.

Dunai TJ. 2000. Scaling factors for production rates of in situ produced cosmogenic nuclides: a critical reevaluation. Earth and Planetary Science Letters 176: 157-169.

Ehlers J, Gibbard P (eds). 2004. Glaciations: Extent and Chronologies. Part III: South America, Asia, Africa, Australia, Antarctica, Developments in Quaternary Science 2. Elsevier: Amsterdam.

Fielding E, Isacks B, Barazangi M, Duncan C. 1994. How flat is Tibet? Geology 22: 163-167.

Finkel RC, Owen LA, Barnard PL, Caffee MW. 2003. Beryllium-10 dating of Mount Everest moraines indicates a strong monsoonal influence and glacial synchroneity throughout the Himalaya. Geology 31: 561-564.
Fort M, Derbyshire E. 1988. Some characteristics of tills in the Annapurna Range, Nepal. In Proceedings of the Second Conference on the Palaeoenvironment of East Asia from the Mid-Tertiary. Vol. 1: Geology, Sea Level Changes, Palaeoclimatology and Palaeobotany, Chen E (ed.). University of Hong Kong: Hong Kong; 195-214.

Frenzel B. 1960. Die Vegetations- und Landschaftszonen Nordeurasiens während der letzten Eiszeit und während der Postglazialen Warmezeit. Akademie der Wissenschaften und der Literatur in Mainz, Abhandlungen der Mathematisch-Naturwissenschaftlichen Klasse 13: 937-1099.

Fuchs M, Owen LA. 2008. Luminescence dating of glacial and associated sediments: a review. Boreas (in press).

Fushimi H. 1977. Glaciations in the Khumbu Himal. Seppyo 39: 60-67. Fushimi H. 1978. Glaciations in the Khumbu Himal. Seppyo 40: 71-77.

Gillespie A, Molnar P. 1995. Asynchronous maximum advances of mountain and continental glaciers. Reviews of Geophysics 33: 311364

Godwin-Austin HH. 1864. On the glaciers of Muztagh Range. Proceedings of the Royal Geographical Society 34: 19-46.

Gosse JC, Phillips FM. 2001. Terrestrial in situ cosmogenic nuclides: theory and application. Quaternary Science Reviews 20: 14751560 .

Guggenberger G, Bäumler R, Zech W. 1998. Weathering of soils developed in eolian material overlying glacial deposits in Eastern Nepal. Soil Science 163: 325-337.

Guyodo Y, Valet JP. 1999. Global changes in intensity of the Earth's magnetic field during the past $800 \mathrm{kyr}$. Nature 399: 249-252.

Haeberli W, Bosch H, Scherler K, Ostrem G, Wallen CC. 1989. World Glacier Inventory: Status 1988. Compiled by the World Glacier Monitoring Service, IAHS-UNEP-UNESCO: Wallingford, UK.

Hahn DG, Shukla J. 1976. An apparent relationship between Eurasian snow cover and Indian monsoon rainfall. Journal of Atmospheric Science 33: 2461-2462.

Hewitt K. 1999. Quaternary moraines vs catastrophic avalanches in the Karakoram Himalaya, northern Pakistan. Quaternary Research 51: 220-237.

Higuchi K, Ageta Y, Yasunari T, Inoue J. 1982. Characteristics of precipitation during the monsoon season in high-mountain areas of the Nepal Himalaya. In Hydrological Aspects of Alpine and High Mountain Areas, Publication 138. IAHS: Wallingford, UK; 21-30.

Hövermann J, Lehmkuhl F. 1994. Die vorzeitlichen Vergletscherungen in Ost- und Zentraltibet. Göttinger Geographische Abhandlungen 95: 71-114.

Hövermann J, Lehmkuhl F, Pörtge K-H. 1993a. Pleistocene glaciations in eastern and central Tibet: preliminary results of the ChineseGerman joint expeditions. Zeitschrift für Geomorphologie 92: 8596.

Hövermann J, Lehmkuhl F, Süssenberger H. 1993b. Neue Befunde zur Paläoklimatologie Nordafrikas und Zentralasiens. Abhandlungen der Braunschweigischen Wissenschaftlichen Gesellschaft 43: 127 150

Inoue J. 1977. Mass budget of Khumbu Glacier. Seppyo 39: 15-19. Inoue J. 1978. Gales over the Himalayas in 1976. Seppyo 40: 56-59. Iwata S. 1976. Late Pleistocene and Holocene moraines in the Sagarmatha (Everest) region, Khumbu Himal. Seppyo 38: 109-114.

Klute F. 1930. Verschiebung der Klimagebiete der letzten Eiszeit. Petermanns Mitteilungen Ergänzungsheft 209: 166-182.

Kuhle M. 1985. Ein subtropisches Inlandeis als Eiszeitauslöser, Südtibet und Mt. Everest expedition 1984. In Georgia Augusta, Nachrichten aus der Universität Gottingen, May; 1-17.

Kuhle M. 1986. The upper limit of glaciation in the Himalayas. Geolournal 13: 331-346.

Kuhle M. 1987. The Problem of a Pleistocene inland glaciation of the Northeastern Qinghai-Xizang Plateau. In Reports of the QinghaiXizang (Tibet) Plateau, Hövermann J, Wang W (eds). Beijing; 250315.

Kuhle M. 1988a. Geomorphological findings on the built-up of Pleistocene glaciation in Southern Tibet and on the problem of inland ice. GeoJournal 17: 457-512.

Kuhle M. 1988b. Topography as a fundamental element of glacial systems. GeoJournal 17: 545-568.

Kuhle M. 1990a. Ice marginal ramps and alluvial fans in semiarid mountains: convergence and difference. In Alluvial Fans: A Field 
Approach, Rachocki AH, Church M (eds). Wiley: Chichester; 55-68.

Kuhle M. 1990b. The cold deserts of high Asia (Tibet and contiguous mountains). GeoJournal 20: 319-323.

Kuhle M. 1991. Observations supporting the Pleistocene inland glaciation of High Asia. Geolournal 25: 131-231.

Kuhle M. 1993. A short report of the Tibet excursion 14-A: part of the XIII INQUA Congress 1991 in Beijing. GeoJournal 29: 426-427.

Kuhle M. 1995. Glacial isostatic uplift of Tibet as a consequence of a former ice sheet. Geolournal 37: 431-449.

Kulkarni AV. 1992. Mass balance of Himalayan glaciers using AAR and ELA methods. Journal of Glaciology 38: 101-104.

Lal D. 1991. Cosmic ray labeling of erosion surfaces: in situ nuclide production rates and erosion models. Earth and Planetary Science Letters 104: 429-439.

Lehmkuhl F. 1995. Geomorphologische Untersuchungen zum Klima des Holozäns und Jungpleistozäns Osttibets. Göttinger Geographische Abhandlungen 102: 1-184.

Lehmkuhl F. 1997. Late Pleistocene, Late-glacial and Holocene glacier advances on the Tibetan Plateau. Quaternary International 38/39: 77-83.

Lehmkuhl F. 1998. Extent and spatial distribution of Pleistocene glaciations in Eastern Tibet. Quaternary International 45/46: 123-134.

Lehmkuhl F, Lui S. 1994. An outline of physical geography including Pleistocene glacial landforms of Eastern Tibet (Provinces Sichuan and Qinghai). Geolournal 34: 7-30.

Lehmkuhl F, Owen LA. 2005. Late Quaternary glaciation of Tibet and the bordering mountains: a review. Boreas 34: 87-100.

Lehmkuhl F, Owen LA, Derbyshire E. 1998. Late Quaternary glacial history of northeastern Tibet. Quaternary Proceedings 6: 121142.

Lehmkuhl F, Klinge M, Rees-Jones J, Rhodes EJ. 2000. First luminescence dates for Late Quaternary aeolian sedimentation in Central and Eastern Tibet. Quaternary International 68/71: 117-132.

Li B, Li J, Cui Z. 1991. (eds). Quaternary glacial distribution map of Qinghai-Xizang (Tibet) Plateau 1:3,000,000. Shi Y (Scientific Advisor). Quaternary Glacier, and Environment Research Center, Lanzhou University, China.

Li JJ, Derbyshire E, Street-Perrott FA, Xu SY, Waters RS. 1984. Glacial and paraglacial sediments of the Hunza valley, north-west Pakistan: a preliminary analysis. In The International Karakoram Project, Miller K (ed.). Cambridge University Press: Cambridge, UK; 496-535.

Lifton NA, Bieber JW, Clem JM, Duldig ML, Evenson P, Humble JE, Pyle R. 2005. Addressing solar modulation and long-term uncertainties in scaling secondary cosmic rays for in situ cosmogenic nuclide applications. Earth and Planetary Science Letters 239: 140-161.

Liu Z, Jiao S, Zhang Y, Yi S, Al C, Zhao Y, Li Y, Wang H, Xu J, Hu J, Guo T. 1988. Geological Map of the Qinghai-Xizang (Tibet) Plateau and adjacent areas $(1: 1,500,000)$. Explanatory note. Chengdu Institute of Geology Resources, Chinese Academy of Geological Sciences, Chengdu, China.

Mann DH, Sletten RS, Reanier RE. 1996. Quaternary glaciation of the Rongbuk Valley, Tibet. Journal of Quaternary Science 11: 267280.

Martinson DG, Pisias NG, Hays JD, Imbrie J, Moore TC, Shackleton NJ. 1987. Age dating and the orbital theory of the ice ages: development of a high resolution 0-300,000-year chronostratigraphy. Quaternary Research 27: 1-29.

Meriaux A-S, Ryerson FJ, Tapponnier P, Van der Woerd J, Finkel RC, Xu X, Xu Z, Caffee MW. 2004. Rapid slip along the central Altyn Tagh Fault: morphochronologic evidence from Cherchen He and Sulamu Tagh. Journal of Geophysical Research 109(B6): B06401.

Miller KJ (ed.). 1984. The International Karakoram Project, (2 vols). Cambridge University Press: Cambridge, UK.

Misch P. 1935. Ein gefalterer junger Sandstein im Nordwest-Himalaya und sein Gefuge. Festschrift zum 60 geburstag von Hans Stille. Verlag: Stuttgart.

Müller F. 1980. Present and late Pleistocene equilibrium line altitudes in the Mt. Everest region: an application of the glacier inventory. World Glacier Inventory 126: 75-94.

Murakami T. 1987. Effects of the Tibetan Plateau. In Monsoon Meteorology, Chang CP, Krishnamurti TN (eds). Oxford University Press: Oxford; 235-270.
Nijampurkar VN, Rao DK. 1992. Accumulation and flow rates of ice on Chhota Shigri glacier, central Himalaya, using radioactive and stable isotopes. Journal of Glaciology 38: 43-50.

Norin E. 1925. Preliminary notes on the Late Quaternary glaciation of the North Western Himalaya. Geografiska Annaler 7: 165-194.

Ohno M, Hamano Y. 1992. Geomagnetic poles over the past 10,000 years. Geophysical Research Letters 19: 1715-1718.

Owen LA. 1988. Wet-sediment deformation of Quaternary and recent sediments in the Skardu Basin, Karakoram Mountains, Pakistan. In Glaciotectonics: Forms and Processes, Croots D (ed.). Balkema: Rotterdam; 123-148.

Owen LA. 1991. Mass movement deposits in the Karakoram Mountains: their sedimentary characteristics, recognition and role in Karakoram landform evolution. Zeitschrift für Geomorphologie 35: 401-424.

Owen LA. 1993. Glacial and non-glacial diamictons in the Karakoram Mountains. In The Formation and Deformation of Glacial Deposits, Croots D, Warren W (eds). Balkema: Rotterdam; 9-29.

Owen LA, Benn DI. 2005. Equilibrium-line altitudes of the Last Glacial Maximum for the Himalaya and Tibet: an assessment and evaluation of results. Quaternary International 138/139: 55-78.

Owen LA, Derbyshire E. 1988. Glacially deformed diamictons in the Karakoram Mountains, northern Pakistan. In Glaciotectonics: Forms and Processes, Croots D (ed.). Balkema: Rotterdam; 149-176.

Owen LA, Derbyshire E. 1989. The Karakoram glacial depositional system. Zeitschrift für Geomorphologie 76: 33-73.

Owen LA, Lehmkuhl F (eds). 2000. Late Quaternary glaciation and paleoclimate of the Tibetan Plateau and bordering mountains. Quaternary International, 65/66: 1-212 pp.

Owen LA, Zhou S (eds). 2002. Glaciation in Monsoon Asia. Quaternary International, 97/98: 1-179 pp.

Owen LA, Bailey RM, Rhodes EJ, Mitchell WA, Coxon P. 1997. Style and timing of Glaciation in the Lahul Himalaya, northern India: a framework for reconstructing the late Quaternary palaeoclimatic change in the Western Himalayas. Journal of Quaternary Science 12: 83-109.

Owen LA, Derbyshire E, Fort M. 1998. The Quaternary glacial history of the Himalaya. Quaternary Proceedings 6: 91-120.

Owen LA, Gualtieri L, Finkel RC, Caffee MW, Benn DI, Sharma MC. 2001. Cosmogenic radionuclide dating of glacial landforms in the Lahul Himalaya, northern India: defining the timing of Late Quaternary glaciation. Journal of Quaternary Science 16: 555-563.

Owen LA, Finkel RC, Caffee MW, Gualtieri L. 2002a. Timing of multiple Late Quaternary glaciations in the Hunza Valley, Karakoram Mountains, northern Pakistan: defined by cosmogenic radionuclide dating of moraines. Geological Society of America Bulletin 114: 593-604.

Owen LA, Kamp U, Spencer JQ, Haserodt K. 2002b. Timing and style of Late Quaternary glaciation in the eastern Hindu Kush, Chitral, northern Pakistan: a review and revision of the glacial chronology based on new optically stimulated luminescence dating. Quaternary International 97/98: 41-55.

Owen LA, Finkel RC, Ma H, Spencer JQ, Derbyshire E, Barnard PL, Caffee MW. 2003a. Timing and style of Late Quaternary glaciations in NE Tibet. Geological Society of America Bulletin 115: 1356-1364.

Owen LA, Ma H, Derbyshire E, Spencer JQ, Barnard PL, Zeng YN, Finkel RC, Caffee MW. 2003b. The timing and style of Late Quaternary glaciation in the La Ji Mountains, NE Tibet: evidence for restricted glaciation during the latter part of the Last Glacial. Zeitschrift für Geomorphologie 130: 263-276.

Owen LA, Spencer JQ, Ma H, Barnard PL, Derbyshire E, Finkel RC, Caffee MW, Zeng YN. 2003c. Timing of Late Quaternary glaciation along the southwestern slopes of the Qilian Shan, Tibet. Boreas 32: 281-291.

Owen LA, Finkel RC, Barnard PL, Haizhou M, Asahi K, Caffee MW, Derbyshire E. 2005. Climatic and topographic controls on the style and timing of Late Quaternary glaciation throughout Tibet and the Himalaya defined by $10 \mathrm{Be}$ cosmogenic radionuclide surface exposure dating. Quaternary Science Reviews 24: 1391-1411.

Owen LA, Caffee MW, Bovard KR, Finkel RC, Sharma MC. 2006a. Terrestrial cosmogenic nuclide surface exposure dating of the oldest glacial successions in the Himalayan orogen. Ladakh Range, northern India. Geological Society of America Bulletin 118: 383-392. 
Owen LA, Finkel RC, Ma H, Barnard PL. 2006b. Late Quaternary landscape evolution in the Kunlun Mountains and Qaidam Basin, Northern Tibet: a framework for examining the links between glaciation, lake level changes and alluvial fan formation. Quaternary International 154/155: 73-86.

Pachur H-J, Wunnemann B, Zhang L, Zhang H, Yuzheng MA. 1994. Floodplain sediments on the divide between Huang He and Chang Jiang in Northwestern China. GeoJournal 34: 97-106.

Paffen KH, Pillewizer W, Schneide HJ. 1956. Forschungen im HunzaKarakoram. Erdkunde 10: 1-33.

Phillips WM, Sloan VF, Shroder JF Jr, Sharma P, Clarke ML, Rendell HM. 2000. Asynchronous glaciation at Nanga Parbat, northwestern Himalaya Mountains, Pakistan. Geology 28: 431-434.

Pigati JS, Lifton NA. 2004. Geomagnetic effects on time-integrated cosmogenic nuclide production with emphasis on in situ ${ }^{14} \mathrm{C}$ and ${ }^{10}$ Be. Earth and Planetary Science Letters 226: 193-205.

Porter SC. 1989. Some geological implications of average Quaternary glacial conditions. Quaternary Research 32: 245-261.

Prell WL, Kutzbach JF. 1987. Monsoon variability over the past 150,000 yr. Journal of Geophysical Research 92: 8411-8425.

Prell WL, Kutzbach JF. 1992. Sensitivity of the Indian monsoon to forcing parameters and implications for its evolution. Nature 360: 647-652.

Richards BWM. 1999. Palaeoclimate of South Asia over the last $80 \mathrm{ka}$ : luminescence ages of sediment from former glaciations in Nepal and Pakistan. PhD thesis, Royal Holloway, University of London, UK.

Richards BWM. 2000. Luminescence dating of Quaternary sediments in the Himalaya and High Asia: a practical guide to its use and limitations for constraining the timing of glaciation. Quaternary International 65/66: 49-61.

Richards BWM, Owen LA, Rhodes EJ. 2000a. Timing of Late Quaternary glaciations in the Himalayas of northern Pakistan. Journal of Quaternary Science 15: 283-297.

Richards BWM, Benn D, Owen LA, Rhodes EJ, Spencer JQ. 2000b. Timing of Late Quaternary glaciations south of Mount Everest in the Khumbu Himal. Nepal. Geological Society of America Bulletin 112: 1621-1632.

Richards BWM, Owen LA, Rhodes EJ. 2001. Comment: asynchronous glaciation at Nanga Parbat, northwestern Himalaya Mountains, Pakistan. Geology 29: 287.

Röthlisberger F, Geyh M. 1985. Glacier variations in Himalayas and Karakoram. Zeitschrift für Gletscherkunde und Glazialgeologie 21: 237-249.

Rupper SB. 2007. Glacier sensitivity and regional climate: past and present. PhD thesis, University of Washington, Seattle, WA.

Rutter NW. 1995. Problematic Ice Sheets. Quaternary International 28: 19-37.

Schäfer JM, Tschudi S, Zhizhong Z, Xihao W, Ivy-Ochs S, Wieler R, Baur H, Kubik PW, Schluchter C. 2002. The limited influence of glaciation in Tibet on global climate over the past 170,000 yr. Earth and Planetary Science Letters 194: 287-297.

Seong YB, Owen LA, Bishop MP, Bush A, Clendon P, Copland P, Finkel R, Kamp U, Shroder JF. 2007. Quaternary glacial history of the Central Karakoram. Quaternary Science Reviews 26: 3384 3405.

Seong YB, Owen LA, Yi C, Finkel RC. 2008a. Quaternary glaciation of Muztag Ata and Kongur Shan: evidence for glacier response to rapid climate changes throughout the Late-glacial and Holocene in westernmost Tibet. Geological Society of America Bulletin (submitted).

Seong YB, Owen LA, Yi C, Finkel RC, Schoenbohm L. 2008b. Geomorphology of anomalously high glaciated mountains at the northwestern end of Tibet: Muztag Ata and Kongur Shan. Geomorphology (in press).

Shackleton NJ, Berger A, Peltier WR. 1990. An alternative astronomical calibration of the lower Pleistocene timescale based on ODP site 677. Transactions of the Royal Society of Edinburgh: Earth Science 81: $251-261$.

Sharma MC, Owen LA. 1996. Quaternary glacial history of the Garhwal Himalaya, India. Quaternary Science Reviews 15: 335-365.

Shi Y. 1988. Map of Snow, Ice, and Frozen Ground in China, Lanzhou Institute of Glaciology and Geocryology. China Cartographic Publishing House: Beijing.
Shi Y. 1992. Glaciers and glacial geomorphology in China. Zeitschrift für Geomorphologie 86: 19-35.

Shi Y. 2002. Characteristics of late Quaternary monsoonal glaciation on the Tibetan Plateau and in East Asia. Quaternary Internationa/ 97/98: 79-91.

Shi Y, Ren B, Wang J, Derbyshire E. 1986. Quaternary glaciation in China. Quaternary Science Reviews 5: 503-510.

Shi Y, Zheng B, Li S. 1992. Last glaciation and maximum glaciation in the Qinghai-Xizang (Tibet) Plateau: a controversy to M. Kuhle's ice sheet hypothesis. Zeitschrift für Geomorphologie 84: 19-35.

Shi Y, Kong Z, Wang S, Tang L, Wang F, Yao T, Zhao X, Zhang P, Shi S. 1993. Mid-Holocene climates and environments in China. Global and Planetary Change 7: 219-233.

Shi Y, Cui Z, Su Z. 2005. The Quaternary Glaciations and Environmental Variations in China. Hebei Science and Technology Publishing House: Hebei, China.

Shiraiwa T. 1993. Glacier fluctuations and cryogenic environments in the Langtang valley, Nepal Himalaya. Contributions from the Institute of Low Temperature Science. Institute of Low Temperature Sciences, Hokkaido University, Sapporo, Japan.

Sirocko F, Sarnthein M, Lange H, Erlenkeuser H. 1991. The atmospheric summer circulation and coastal upwelling in the Arabian Sea during the Holocene and the last glaciation. Quaternary Research 36: 72 93.

Soman MK, Slingo J. 1997. Sensitivity of the Asian summer monsoon to aspects of sea-surface-temperature anomalies in the tropical Pacific Ocean. Quarterly Journal of the Royal Meteorological Society 123 : 309-336.

Spencer JQ, Owen LA. 2004. Optically stimulated luminescence dating of Late Quaternary glaciogenic sediments in the upper Hunza valley: validating the timing of glaciation and assessing dating methods. Quaternary Sciences Reviews 23: 175-191.

Staiger J, Gosse J, Toracinta R, Oglesby B, Fastook J, Johnson JV. 2007. Atmospheric scaling of cosmogenic nuclide production: climate effect. Journal of Geophysical Research 112: B02205.

Stone JO. 2000. Air pressure and cosmogenic isotope production. Journal of Geophysical Research 105: 23753-23759.

Stroeven RP, Hättestrand C, Heyman J, Harbor J, Li YK, Zhou LP, Caffee MW, Alexanderson H, Kleman J, Ma HZ, Liu GN. 2008. Landscape analysis of the Huang He headwaters, NE Tibetan Plateau: patterns of glacial and fluvial erosion. Geomorphology (in press).

Thompson LG. 2000. Ice core evidence for climate change in the Tropics: implications for our future. Quaternary Science Reviews 19: 19-35.

Thompson LG, Mosley-Thompson E, Davis ME, Bolzan JF, Dai J, Yao T, Gundestrup N, Wu X, Klein L, Xie Z. 1989. Holocene-Late Pleistocene climatic ice core records from Qinghai-Tibetan Plateau. Science 246: 474-477.

Thompson LG, Yao T, Davis ME, Henderson KA, Mosley-Thompson E, Lin P-N, Beer J, Synal HA, Cole-Dai J, Bolzan JF. 1997. Tropical climate instability: the Last Glacial Cycle from a Qinghai-Tibetan ice core. Science 276: 1821-1825.

Thompson T. 1849. Successful journey to the Karakoam Pass, in Central Asia. Journal of the Royal Geographical Society 19: 25-29.

Trinkler E. 1930. The Ice-Age on the Tibetan Plateau and in the adjacent region. Geography Journal 75: 225-232.

Tsukamoto S, Asahi K, Watanabe T, Kondo R, Rink WJ. 2002. Timing of past glaciation in Kanchenjunga Himal, Nepal by optically stimulated luminescence dating of tills. Quaternary International 97/98: 57-68.

van Williams S. 1983. Present and former equilibrium-line altitudes near Mount Everest, Nepal and Tibet. Arctic and Alpine Research 15: 201-211.

von Wissmann H. 1959. Die heutige Vergletscherung und Schneegrenze in Hochasien mit Hinweisen auf die Vergletscherung der letzten Eiszeit. Akademie der Wissenschaften und der Literatur in Mainz, Abhandlungen der Mathematisch-Naturwissenschaftlichen Klasse 14: 121-123.

Wake CP, Mayewski PA, Dahe Q, Qinzhao Y, Sichang K, Whitlow S, Meeker LD. 2001. Changes in atmospheric circulation over the south-eastern Tibetan Plateau over the last two centuries from a Himalayan ice core. PAGES News 9: 3. 
Wang J. 1987. Climatic geomorphology of the northeastern part of the Qinghai-Xizang Plateau. In Reports on the Northeastern Part of the Qinghai-Xizang (Tibet) Plateau, Hovermann J, Wang W (eds). Science Press: Beijing; 140-175.

Webster PJ. 1987a. The elementary monsoon. In Monsoons, Fein JS, Stephens PJ (eds). Wiley: New York; 3-32.

Webster PJ. 1987b. The variable and interactive monsoon. In Monsoons, Fein JS, Stephens PJ (eds). Wiley: New York; 269-330.

Yang S, Odah H, Shaw J. 2000. Variations in the geomagnetic dipole movement over the last 12,000 years. Geophysical Journal International 140: 158-162.

Yasunari T, Inoue J. 1978. Characteristics of monsoonal precipitation around peaks and ridges in Shorong and Khumbu Himal. Seppyo 40: 26-32.

Yi C, Owen LA. 2006. Quaternary palaeoenvironmental change in Tibet and the bordering mountains. Quaternary International 154/ 155: 1-157 pp.

Yi C, Li X, Qu J. 2002. Quaternary glaciation of Puruogangri: the largest modern ice field in Tibet. Quaternary International 97/98: 111-123.

Yin A, Harrison TM. 2000. Geologic evolution of the HimalayanTibetan orogen. Annual Reviews of Earth and Planetary Sciences 28: $211-280$.

Zech R, Abramowski U, Glaser B, Sosin P, Kubik PW, Zech W. 2005. Late Quaternary glacier and climate history of the Pamir Mountains derived from cosmogenic ${ }^{10}$ Be exposure ages. Quaternary Research 64: 212-220.

Zech W, Glaser B, Ni A, Petrov M, Lemzin I. 2000. Soil as indicators of the Pleistocene and Holocene landscape history: Alay Range (Khyrgstan). Quaternary International 65/66: 161-170.

Zech W, Glaser B, Abramowski U, Dittmar C, Kubik PW. 2003. Reconstruction of the Late Quaternary Glaciation of the Macha Khola valley (Gorkha Himal, Nepal) using relative and absolute $\left({ }^{14} \mathrm{C},{ }^{10} \mathrm{Be}\right.$, dendrochronology) dating techniques. Quaternary Science Reviews 22: 2253-2265.

Zeitler PK, Meltzer AS, Koons PO, Craw D, Hallet B, Chamberlain CP, Kidd WSF, Park SK, Seeber L, Bishop M, Shroder JF. 2001. Erosion, Himalayan geodynamics and the geomorphology of metamorphism. GSA Today 11: 4-8.

Zhang X, Shi Y. 1980. Changes of the Batura Glacier in the Quaternary and recent times. In Professional Papers on the Batura Glacier, Karakoram Mountains. Science Press: Beijing; 173-190.

Zheng B. 1989. Controversy regarding the existence of a large ice sheet on the Qinghai-Xizang (Tibetan) Plateau during the Quaternary Period. Quaternary Research 32: 121-123.

Zheng B, Rutter N. 1998. On the problem of Quaternary glaciations, and the extent and patterns of Pleistocene ice cover in the QinghaiXizang (Tibet) plateau. Quaternary International 45/46: 109122. 